\title{
Glycinin-induced porcine IPEC-J2 cell damage via the NF-KB/MAPK signaling pathway
}

Chenglu Peng

Anhui Agricultural University

\section{Zhifeng Sun}

Anhui Agricultural University

Lei Wang

Anhui Agricultural University

Yingshuang Shu

Anhui Agricultural University

\section{Mengchu He}

Anhui Agricultural University

Hongyan Ding

Anhui Agricultural University

Yu Li

Anhui Agricultural University

\section{Xichun Wang}

Anhui Agricultural University

\section{Shibin Feng}

Anhui Agricultural University

Jinchun Li

Anhui Agricultural University

Jinjie Wu ( $\nabla$ wjj@ahau.edu.cn )

Anhui Agricultural University https://orcid.org/0000-0001-9706-0808

Research article

Keywords: IPEC-J2, glycinin, nuclear factor-kappa B, mitogen-activated protein kinase

Posted Date: March 12th, 2020

DOl: https://doi.org/10.21203/rs.3.rs-16881/v1

License: (c) (i) This work is licensed under a Creative Commons Attribution 4.0 International License. Read Full License 


\section{Abstract}

Background: Glycinin, a protein found in soybean, is a human and animal allergen. It been previously shown to damage the intestinal barrier. However, its mechanisms of action remain unclear. Therefore, in this study, the intestinal porcine epithelial cell line IPEC-J2 was used to study the effect of glycinin concentration on the intestinal epithelium and identify the related signaling pathways. Results: IPEC-J2 cells were divided into seven treatment groups and a control group; the cells were treated for $24 \mathrm{~h}$ with 1 , 5 , or $10 \mathrm{mg} / \mathrm{mL}$ glycinin or with $5 \mathrm{mg} / \mathrm{mL}$ glycinin after 30 min of pre-treatment with $1 \mu \mathrm{mol} / \mathrm{L}$ nuclear factor-kappa B (NF-kB) inhibitor (pyrrolidine dithiocarbamate), inducible nitric oxide synthase inhibitor (Nw-nitro-l-arginine methyl ester), Jun N-terminal kinase (JNK) inhibitor (SP600125), or p38 inhibitor (SB202190). A series of molecular and biochemical experiments revealed that the levels of NF-kB, p38, and JNK, as well as their downstream proteins, increased after the treatment compared with those in the control group.

\section{Background}

Many studies have shown that soy-containing foods have a positive impact on health; for example, they reduce the prevalence of high cholesterol levels, cancer (Mace, et al.,2019), acute malnutrition (Hossain, et al.,2019), and obesity (Zhang, et al.,2019). Therefore, the use of soybeans in the food and feed industries has been increasing. Piglets are especially susceptible to soybean-induced intestinal damage when weaned onto glycinin-containing diets (Zheng, et al.,2014, Peng, et al.,2018, Zheng, et al.,2018). Soybean is considered an important source of allergens for both humans and animals (Liu, et al.,2008, Weidmann, et al.,2018). The major seed protein in soybean, glycinin, has been determined as the main food allergen (Sun, et al.,2008, Koepke, et al.,2017). Glycinin dissociates into acidic (A, 31-45 kDa) and basic (B, 18-20 kDa) polypeptide chains (Maruyama, et al.,2004). A1aB2 (G1), A1bB1b (G2), A2B1a (G3), A3B4 (G4), and A5A4B3 (G5) are the five major subunits that have been characterized in glycinin (Ma, et al.,2010). Tight junctions (TJs) are essential proteins, which include claudins, occludin, and junctional adhesion molecules, for safeguarding animal intestinal health. These proteins are aggregated and stabilized by cytoplasmic scaffold proteins known as zonula occludens (ZO) and the cytoskeletal protein F-actin (Zhai, et al.,2018, Cui, et al.,2019). Researchers demonstrated that glycinin reduced the expression of TJ proteins in the intestinal porcine epithelial cell line IPEC-J2 (Zhao, et al., Zhao, et al.,2008, Jiang, et al.,2015, Cui, et al.,2019). However, the mechanism by which glycinin damages the intestinal barrier is unclear. Therefore, developing a better understanding of soybean allergies remains an important task.

The intestinal tract digests the chyme from the stomach and absorbs nutrients into the blood and lymph; moreover, it also protects against the entrance of harmful entities (Zhao, et al., Jiang, et al.,2015). Soybean allergies usually cause intestinal inflammatory diseases and induce intestinal cell proliferation, apoptosis, and migration (Zhao, et al., year Qiao, et al.,2003). However, only a few studies have investigated the effects of glycinin on the mechanisms of signaling pathways. 
The feeding conditions, feeding patterns, and nutrient sources directly affect epithelial cell proliferation and differentiation, which are primarily regulated by mitogen-activated protein kinase (MAPK). There are three downstream MAPK pathways: the extracellular signal-regulated kinase (ERK), p38, and Jun Nterminal kinase (JNK) pathways. They are typically activated in the rapidly dividing intestinal cells (Osaki, et al.,2013). In addition, nuclear factor-kappa B (NF-KB) is a critical regulator of pro-inflammatory gene expression, which causes the transcription of pro-inflammatory cytokines, chemokines, adhesion molecules, matrix metalloproteinases, cyclooxygenase-2 (COX-2), and inducible nitric oxide synthase (iNOS) production (Tak, et al.,2001, Li, et al.,2002). iNOS at elevated levels could bind to receptors on the cell surface and ultimately activate NF-KB. Moreover, tumor necrosis factor-a (TNF-a) could also activate NF-KB (Suh, et al.,). NF-KB and the activator protein-1 (AP-1) complex (composed of c-Fos and c-Jun subunits) play critical roles in the transcriptional regulation of genes that encode inflammatory mediators (Zenz, et al.,2008).

We used the IPEC-J2 cell line as it closely mimics the intestine. Non-transformed IPEC-J2 cells can be separated from the small intestine of a pig. An IPEC-J2 culture is the most effective porcine epithelial cell model because it retains most of its epithelial nature (Mariani, et al.,). The severity of an allergic reaction to glycinin depends on its concentration; higher concentrations induce a more severe allergic reaction (Sun, et al.,2008). Our previous research identified that $\beta$-conglycinin causes IPEC-J2 cell damage (Peng, et al.,2019). Therefore, we used different concentrations of glycinin in this study. Based on the known effects of glycinin on intestinal permeability and our previous observations on the effects of soybean antigen proteins in piglets (Chenglu, et al.,, Peng, et al.,2018), we hypothesized that glycinin causes IPECJ2 cell damage. IPEC-J2 cells were applied as an intestinal epithelial cell model to illustrate the effect of glycinin on cells and verify our previous in vivo experiments. We also demonstrated the potential molecular mechanism of glycinin-induced IPEC-J2 cell damage by adding various inhibitors.

\section{Results}

\section{Purity of $\beta$-conglycinin}

Sodium dodecyl sulfate-polyacrylamide gel electrophoresis (SDS-PAGE) analysis for glycinin showed that it contained two bands, including acidic and basic subunits (Fig. 1). The purity of glycinin was approximately $90 \%$.

\section{Cell viability after glycinin exposure}

To illustrate the effects of glycinin on IPEC-J2 cells, the viability of the cells was analyzed $24 \mathrm{~h}$ after exposure to different concentrations of glycinin (groups $B-D$ ) alone or in presence of different pathway inhibitors [group 11, NF-KB inhibitor: pyrrolidine dithiocarbamate (PDTC); I2, iNOS inhibitor: N-w-nitro-Iarginine methyl ester (L-NAME); I3, JNK inhibitor: SP600125; and I4, p38 inhibitor: SB202190]. Compared to that in group $A$ (untreated control cells), cell viability significantly decreased in the above-mentioned 
treatment groups (Fig. 2a). Compared to that in group C (intermediate concentration of glycinin), the viability of IPEC-J2 cells in groups I1, I2, I3, and I4 significantly increased $(p<0.01$ or $p<0.05)$.

\section{Alkaline phosphatase (ALP) activity analysis}

As shown in Fig. 2b, ALP levels were significantly upregulated in groups B-14 compared to those in group $A(p<0.01$ or $p<0.05)$. However, ALP levels were significantly downregulated in groups $11,12,13$, and 14 compared to those in group $C(p<0.01)$.

\section{Enzyme-linked immunosorbent assay (ELISA)}

As shown in Fig. 3, the levels of caspase-3, caspase-8, TNF-a, interferon-a, COX-2, 5-HT, interleukin (IL)-2, IL-6, and IL-4 were significantly enhanced in the treatment groups compared to those in group A $(\mathrm{p}<$ 0.01 ). However, the levels decreased significantly in groups $I 1, I 2, I 3$, and 14 compared to those in group $C$ $(p<0.01)$.

\section{Transmission electron microscopy}

As shown in Fig. 4, IPEC-J2 cells in group A showed intact nuclei with uniform chromatin dispersion, whereas those in group $C$ showed mitochondrial alterations. In group $D$, cells showed vesicles in the cytoplasm, mitochondria, and endoplasmic reticulum, while the nucleus itself was decomposed into many discrete fragments. Moreover, highly concentrated chromatin was found near the inner core membrane of cells in group D. Compared to that of cells in group C, the internal structure of IPEC-J2 cells in groups $11,12,13$, and 14 was relatively complete and regular; the cytoplasmic density was superior, the mitochondria and endoplasmic reticulum were complete, and the chromatin in the nucleus was homogenously dispersed.

\section{Effect of glycinin on TJ and cytoskeleton proteins of IPEC- $\mathrm{J} 2$ cells}

The effects of glycinin on the TJ (occludin, claudin-1, and ZO-1) and cytoskeleton proteins are shown in Figs. 5 and 6 . The expression of TJ proteins was investigated by western blot analysis, quantitative realtime polymerase chain reaction (qRT-PCR), and immunofluorescence, whereas that of the cytoskeleton proteins was investigated by immunofluorescence. In the groups treated with glycinin, protein and mRNA expression of TJs was significantly decreased $(p<0.01$ or $p<0.05)$. However, the expression of TJ protein and mRNA in IPEC-J2 cells of groups I1, I2, I3, and 14 was significantly increased compared to that in group $C(p<0.01$ or $p<0.05)$.

The immunofluorescence signals of the TJs in groups B, C, and D were significantly weaker than those of group $A$, and the cellular junction location was obscure, indicating that the expression of TJ proteins was 
lower than that in the control group. However, the TJ proteins in groups $11,12,13$, and 14 were complete and more regular than those in group $\mathrm{C}$ and were clearly identifiable at the cell-cell contact regions.

As shown in Fig. 7, the cytoskeleton proteins in group B were slightly degraded, while those in groups $C$ and $D$ were severely degraded. However, the cytoskeletal proteins in groups $11,12,13$, and 14 were only slightly degraded. The addition of inhibitors diminished glycinin-induced intestinal barrier dysfunction, as well as TJs.

\section{Effect of glycinin on NF-KB/MAPK-related mRNA and protein expression}

The relative mRNA expression of NF-kB, iNOS, JNK, p38, and their downstream genes was significantly increased $(p<0.01$ or $p<0.05)$ in groups $B, C$, and $D$, compared to that in group A (Fig. 8). However, preincubation with the inhibitors significantly inhibited the glycinin-induced expression of NF-KB, JNK, p38, iNOS, and their associated genes in groups $11,12,13$, and $14(p<0.01$ or $p<0.05)$.

The results of the western blot analysis are shown in Figs. 9 and 10. Glycinin significantly increased ( $<<$ 0.01 or $p<0.05$ ) the phosphorylation levels of JNK, p38, ERK, NF-KB p65, c-Fos, c-Jun, and I kappa B kinase $(\mathrm{IKK}) \mathrm{a} / \beta$. However, phosphorylation was lower in groups $\mathrm{I1}, \mathrm{I} 2, \mathrm{I}$, and $\mathrm{I} 4$ than in group $\mathrm{C}(\mathrm{p}<0.01$ or $\mathrm{p}<0.05)$.

As shown in Fig. 11, compared with group A, groups $B, C$, and D showed significant increases in the expression of NF-kB proteins (red signal). In the control group, NF-kB was mainly expressed in the cytoplasm. However, glycinin treatment increased the expression of NF-KB proteins in the nucleus.

\section{Analysis of cell apoptosis rate by flow cytometry}

As shown in Fig. 12, glycinin increased the proportion of apoptotic IPEC-J2 cells. The rate of apoptosis was significantly increased in groups $B, C$, and $D$, compared to that in the control group $(p<0.01)$. However, the apoptosis rate was decreased in groups $11,12,13$, and 14 , compared to that in group $C(p<$ $0.01)$.

\section{Electrophoretic mobility shift assay (EMSA)}

A significant correlation was observed between glycinin concentration and the DNA-binding activity of NF-KB p65, cAMP response element-binding (CREB), and AP-1 subunit in the IPEC-J2 cells. The NF-KB p65, CREB, and AP-1 DNA-binding activities were significantly increased in groups $B, C$, and $D$, compared to those in group $A(p<0.01 ;$ Fig. 13). However, the binding activities were significantly decreased in groups $11,12,13$, and 14 , compared to those in group $C(p<0.01)$.

\section{Discussion}


The effect of glycinin on signaling pathways of intestinal damage in epithelial cells remains elusive. The TJs are generally known to create continuous cell-cell contacts, which form paracellular barriers and pores that determine their permeability and form an intercellular barrier, sealing off the intercellular space between adherent epithelial cells (Peng, et al.,2019). In the gastrointestinal tract, the claudins and occludin are TJ proteins expressed in apical and basal positions in the lateral membrane, respectively. ZO proteins, such as ZO-1, maintain the complex integrity of TJs primarily by linking claudins, occludin, and cytoskeletal proteins (Günzel2013, Odenwald, et al.,2016). Overall, the TJ-cytoskeleton structure is an essential part of the intestinal barrier. The function of TJs depends on their protein expression level and membrane distribution (Akiyama, et al.,).

In the present study, we determined the expression and distribution of claudin-1, ZO-1, and occludin by western blotting and cell immunofluorescence and studied their cytoskeletal structures by cell immunofluorescence. Results indicated that glycinin disrupted the TJ and cytoskeletal structures and increased epithelial permeability, resulting in IPEC-J2 cell injury and apoptosis in a concentrationdependent manner. Chen et al. reported that glycinin caused intestinal injury by inhibiting the growth of intestinal cells, damaging the cytoskeleton, and inducing apoptosis in piglets (Chen, et al.,). Intestinal ALP has the basic function of maintaining epithelial integrity, and its loss may increase inflammation and sepsis permeability. Increased ALP levels indicated that glycinin damaged cell membranes. Furthermore, the flow cytometry results indicated that glycinin significantly increased the proportion of apoptotic cells. However, the addition of NF-KB, iNOS, JNK, and p38 inhibitors efficiently prevented glycinin-induced apoptosis.

Zhao et al. investigated the epithelial permeability, integrity, metabolic activity, and TJ distribution and expression in IPEC-J2 cells treated with glycinin (Zhao, et al.,). They reported that the expression of claudin-3, occludin, and ZO-1 were reduced. Our findings are consistent with their findings; however, the mechanism behind these effects has not been previously elucidated. In our previous studies, we found that glycinin impaired intestinal function by affecting NF-KB, JNK, and p38 expression in piglets (Hao, et al.,2009). Herein, we demonstrate that glycinin caused intestinal barrier damage in vitro in IPEC-J2 cells. To assess whether the damaging effects of glycinin are associated with apoptosis in vitro, further research needs to be conducted.

Western blotting results demonstrated that the phosphorylation levels of MAPK, NF-KB, and their associated proteins were significantly upregulated after treatment with glycinin; however, these levels were significantly decreased when cells were pre-treated with inhibitors for $30 \mathrm{~min}$. The results of the relative mRNA expression levels of apoptosis-associated genes were consistent with those of western blotting. Furthermore, IPEC-J2 cell activity was improved when inhibitors were added to block glycinininduced apoptosis. Based on these findings, we inferred that glycinin induces IPEC-J2 cell damage by upregulation of NF-KB/MAPK.

Three well-characterized MAPK proteins (ERK, JNK, and p38) are activated in response to a variety of extracellular stimuli, widely mediating signal transduction from the cell surface, and are involved in cell 
proliferation, apoptosis, differentiation, and movement in mammals (Cargnello, et al.,2011). The NF-KB and MAPK signaling pathways are essential for the expression and production of several proinflammatory cytokines and mediators (Kim, et al.,2010, Roy, et al.,2016). The regulation of cell functions by MAPKs is mediated majorly via the phosphorylation of their downstream substrates, including AP-1, which is a dimeric transcription factor composed of the Jun, Fos, and automatic transmission fluid subunits that forms a variety of homodimers (complexation of identical monomers) and heterodimers (complexation of non-identical monomers) binding to a common DNA site, the AP-1 binding site sequence. Additionally, it has been established that AP-1 is mediated by various signaling molecules, such as ERK1/2 and JNK (Martin, et al.,2003).

The EMSA results indicated that glycinin increased the AP-1 binding activity, and the qRT-PCR results indicated that glycinin upregulated the relative mRNA expression levels of AP-1. However, after pretreatment of IPEC-J2 cells with $1 \mu \mathrm{mol} / \mathrm{L}$ JNK or p38 inhibitor, the AP-1 binding activity and relative mRNA expression levels were significantly decreased. ALP activity demonstrated a significant increase, indicating the destruction of cellular integrity induced by glycinin, which is consistent with the changes in the expression of TJ and cytoskeleton proteins. It has been shown that p38 MAPK can induce CREB binding to cAMP response elements (Shaywitz, et al.,1999).

In the present study, CREB binding activity and relative mRNA expression levels were remarkably increased after glycinin treatment; however, pre-treatment of IPEC-J2 cells with the JNK inhibitor significantly reduced the CREB binding activity and relative mRNA expression levels, consistent with the results of AP- 1 activity. In addition, the activation of MAPK is critical for the production of inflammatory mediators by controlling NF-KB activity (Suh, et al.,2006). The released NF-KB subunit translocates into the nucleus and promotes the transcription of genes such as TNF- $a$ and IL-6 (Li, et al.,2016). In this study, the NF-KB phosphorylation levels, protein expression, and binding activity were significantly increased after glycinin treatment; pre-treatment of IPEC-J2 cells with NF-KB and iNOS inhibitors significantly decreased the mentioned parameters, which was in agreement with the results of EMSA. The relative mRNA expression of apoptosis-associated genes, including IKKß, iNOS, and IKKa, was significantly increased with increasing concentrations of glycinin; however, these were significantly decreased when IPEC-J2 cells were pre-treated with NF-KB, iNOS, JNK, or p38 inhibitors. These results were consistent with those observed for the expression of apoptosis-related proteins.

In conclusion, our study provides insights into the mechanism of glycinin-induced intestinal cell damage and the associated signaling pathways. In agreement with our hypothesis, our findings suggest that glycinin causes injury to IPEC-J2 cells through the NF-KB/MAPK signaling pathway.

\section{Materials And Methods}

Preparation of glycinin 
Glycinin was provided by Professor Shuntang Guo of the College of Food Science and Nutritional Engineering at China Agricultural University (Patent No: 200,410,029,589.4, China). The purified product contained over $90 \%$ glycinin, determined by SDS-PAGE analysis, as reported by Hao et al. to guarantee the best quantitative determination (Hao, et al.,2009).

\section{Cell culture and reagents}

The IPEC-J2 cell line was obtained from China Center for Type Culture Collection (Wuhan, China) and was cultured in RPMI-1640 medium (Thermo Fisher Scientific, Waltham, MA, USA) containing $10 \%$ fetal bovine serum (Clark Bioscience, Richmond, VA, USA), $100 \mathrm{U} / \mathrm{mL}$ penicillin, and $100 \mu \mathrm{g} / \mathrm{mL}$ streptomycin in a humidified incubator with $5 \% \mathrm{CO}_{2}$ at $37^{\circ} \mathrm{C}$. The culture medium was changed every day.

\section{Experimental design}

After 24-h culture, IPEC-J2 cells were divided into eight groups: A (control group; untreated cells), B (1 mg/mL glycinin group), C (5 mg/mL glycinin group), D (10 mg/mL glycinin group), 11 [ $5 \mathrm{mg} / \mathrm{mL}$ glycinin $+1 \mu \mathrm{mol} / \mathrm{L}$ pyrrolidine dithiocarbamate (PDTC) group], 12 [5 mg/mL glycinin $+1 \mu \mathrm{mol} / \mathrm{mL} \mathrm{N}-\omega$ nitro-l-arginine methyl ester (L-NAME) group], I3 ( $5 \mathrm{mg} / \mathrm{mL}$ glycinin $+1 \mu \mathrm{mol} / \mathrm{L}$ SP600125 group), and 14 ( $5 \mathrm{mg} / \mathrm{mL}$ glycinin $+1 \mu \mathrm{mol} / \mathrm{L}$ SB202190 group). The treated groups B, C, and D were cultured with the indicated concentrations of glycinin for $24 \mathrm{~h}$. Groups $11,12,13$, and 14 were pre-treated with the different pathway inhibitors PDTC, L-NAME (Beyotime Biotechnology, Shanghai, China), SP600125, or SB202190 (MedChem Express, Shanghai, China) for 30 min.

\section{Measurement of cell viability}

Cell proliferation was determined by the Cell Counting Kit-8 (CCK-8; Dojindo Molecular Technologies, Kumamoto, Japan) assay. Briefly, cells were plated in $96-$ well plates at a density of $2 \times 10^{3}$ cells/well and incubated overnight. Then, cells were treated for $24 \mathrm{~h}$ with 1,5 , or $10 \mathrm{mg} / \mathrm{mL}$ glycinin or with $5 \mathrm{mg} / \mathrm{mL}$ glycinin after pre-treatment with $1 \mu \mathrm{mol} / \mathrm{L}$ NF-KB inhibitor (PDTC), iNOS inhibitor (L-NAME), JNK inhibitor (SP600125), or p38 inhibitor (SB202190). Next, $10 \mu \mathrm{L}$ CCK-8 reagent was added to each well, and plates were incubated for $1 \mathrm{~h}$ at $37^{\circ} \mathrm{C}$. A Multiskan MS plate reader (Thermo Fisher Scientific) was used to measure optical density values at $450 \mathrm{~nm}$.

\section{ALP activity}

Cell membrane integrity was determined by measuring ALP levels in the supernatant. Cells were treated with glycinin and inhibitors, as described above. After treatment, cell culture supernatant was collected, and the ALP level was detected using an ALP test kit according to the manufacturer's instructions (Jiancheng, Nanjing, China).

\section{ELISA}

Caspase-3/-8 and COX-2 levels were measured after treatment of IPEC-J2 cells with glycinin and inhibitors using ELISA to detect the expression of pro-inflammatory cytokines, according to the 
manufacturer's instructions (Nanjing SenBeiJia Biological Technology Co., Ltd., Nanjing, China). First, 500 $\mu \mathrm{L}$ of $0.1 \mathrm{~mol} / \mathrm{L}$ Tris- $\mathrm{HCl}$ (Beyotime Biotechnology; $\mathrm{pH}=7.4$ ) containing $0.1 \%$ Triton X-100 (Beyotime Biotechnology) was mixed with each sample. Subsequently, each sample was subjected to prolonged sonication in ice-cold water, the obtained cell lysate was centrifuged at $1000 \times \mathrm{g}$ for $10 \mathrm{~min}$, and the supernatant was collected. The concentrations of COX-2 and caspases were determined from the standard curves.

\section{Transmission electron microscopy}

After treatment, samples were cut into ultrathin sections (less than $1 \mathrm{~mm}^{3}$ ) with a glass knife on an ultramicrotome. The sections were stained with aqueous strontium, and digital images were taken using a JEM-1230 transmission electron microscope (JEOL, Akishima, Tokyo, Japan). The transmission electron microscope protocols were as described in our previous study (Peng, et al.,2019).

\section{qRT-PCR}

IPEC-J2 cells were plated into a 24-well plate at a density of $1.3 \times 10^{6}$ cells/well and cultured overnight. The total RNA was extracted from IPEC-J2 cells using RNAiso Plus (TaKaRa Biotechnology, Shiga, Japan). The relative gene expression levels were determined using the $2^{-\Delta \Delta C t}$ method. For each sample, $500 \mathrm{ng}$ of total RNA was reverse transcribed (AT341, TransGen, Beijing, China). The PCR protocol was as follows: a step at $95^{\circ} \mathrm{C}$ for $30 \mathrm{~s}$, followed by 40 cycles at $95{ }^{\circ} \mathrm{C}$ for $5 \mathrm{~s}$ and $60{ }^{\circ} \mathrm{C}$ for $30 \mathrm{~s}$, according to the manufacturer's protocol. The primer sequences used for qRT-PCR amplification are shown in Table 1. 
Table 1

Primer sequences for qRT-PCR amplification.

\begin{tabular}{|c|c|c|c|c|}
\hline Gene & Accession number & Primer & Sequences $\left(5^{\prime} \rightarrow 3^{\prime}\right)$ & Product \\
\hline \multirow[t]{2}{*}{ p38 } & \multirow[t]{2}{*}{ XM_001929490.5 } & Forward & AAGACTCGTTGGAACCCCAG & \multirow[t]{2}{*}{$150 \mathrm{bp}$} \\
\hline & & Reverse & TCCAGCAAGTCAACAGCCAA & \\
\hline \multirow[t]{2}{*}{ JNK } & \multirow[t]{2}{*}{ NC_010456.5 } & Forward & CAAGCACCTTCACTCTGCTG & \multirow[t]{2}{*}{$168 \mathrm{bp}$} \\
\hline & & Reverse & TCAGGTGCTCTGTAGTAGCG & \\
\hline \multirow[t]{2}{*}{ iNOS } & \multirow[t]{2}{*}{ NM_001143690.1 } & Forward & GGGTCAGAGCTACCATCCTC & \multirow[t]{2}{*}{$114 \mathrm{bp}$} \\
\hline & & Reverse & CGTCCATGCAGAGAACCTTG & \\
\hline \multirow[t]{2}{*}{$\mathrm{IKKa}$} & \multirow[t]{2}{*}{ NM_001114279.1 } & Forward & САCTCTTACAGCGACAGCAC & \multirow[t]{2}{*}{$145 \mathrm{bp}$} \\
\hline & & Reverse & CCACCTTGGGCAGTAGATCA & \\
\hline \multirow[t]{2}{*}{$\mathrm{IKK} \beta$} & \multirow[t]{2}{*}{ NM_001099935.1 } & Forward & ACCTGGCTCCCAACGACTT & \multirow[t]{2}{*}{$184 \mathrm{bp}$} \\
\hline & & Reverse & AGATCCCGATGGATGATTCTG & \\
\hline \multirow[t]{2}{*}{ COX-2 } & \multirow[t]{2}{*}{ NC_000845.1 } & Forward & TGCACGGCGGCAATATTAAA & \multirow[t]{2}{*}{$156 \mathrm{bp}$} \\
\hline & & Reverse & AGTGGAAGTGTGCGACTACA & \\
\hline \multirow[t]{2}{*}{ NF-kB p65 } & \multirow[t]{2}{*}{ ID:100514505 } & Forward & СTCGCTCGCACTCTTGCTCTC & \multirow[t]{2}{*}{$173 \mathrm{bp}$} \\
\hline & & Reverse & AATAGGCGGACGAGGCAGAAG & \\
\hline \multirow[t]{2}{*}{ ZO-1 } & \multirow[t]{2}{*}{ NC_010443.5 } & Forward & GGGCTCTTGGCTTGCTATTC & \multirow[t]{2}{*}{$160 \mathrm{bp}$} \\
\hline & & Reverse & AAGGCCTCGGAATCTCCAAA & \\
\hline \multirow[t]{2}{*}{ Claudin-1 } & \multirow[t]{2}{*}{ NC_010455.5 } & Forward & GGCAGATCCAGTGCAAAGTC & \multirow[t]{2}{*}{$94 \mathrm{bp}$} \\
\hline & & Reverse & CCCAGCAGGATGCCAATTAC & \\
\hline \multirow[t]{2}{*}{ Occludin } & \multirow[t]{2}{*}{ NC_010458.4 } & Forward & CATTATGCACCCAGCAACGA & \multirow[t]{2}{*}{$168 \mathrm{bp}$} \\
\hline & & Reverse & GCACATCACGATAACGAGCA & \\
\hline \multirow[t]{2}{*}{ AP-1 } & \multirow[t]{2}{*}{ NC_010448.4 } & Forward & GGTGGCCCAGCTTAAACAAA & \multirow[t]{2}{*}{72 bp } \\
\hline & & Reverse & AACTGCTGCGTTAGCATGAG & \\
\hline CREB & NC_010457.5 & Forward & TTGCCACATTAGCCCAGGTA & $67 \mathrm{bp}$ \\
\hline & & Reverse & AAAGTTACGGTGGGAGCAGA & \\
\hline actin & 414396 & Forward & CTGGACTTCGAGCAGGAGATGG & $168 \mathrm{bp}$ \\
\hline & & Reverse & TTCGTGGATGCCGCAGGATTC & \\
\hline
\end{tabular}




\section{Western blot analysis}

Western blotting was used to detect protein concentrations as described previously (Peng, et al.,2019). Briefly, cells were washed with phosphate-buffered saline (PBS), homogenized in $150 \mu \mathrm{L}$ ice-cold RIPA lysis buffer (Beyotime Biotechnology), and then centrifuged to collect the supernatant. The protein concentration in the supernatant was determined by the bicinchoninic acid protein assay according to the manufacturer's instructions (Beyotime Biotechnology). All protein samples were subjected to the same treatment and were adjusted to equal concentrations. Samples were diluted with $5 \times$ loading buffer and then heated at $95{ }^{\circ} \mathrm{C}$ for $5 \mathrm{~min}$. Equal amounts of total protein were subjected to electrophoresis on $10 \%$ SDS-PAGE and then transferred to a polyvinylidene fluoride membrane (Millipore, Billerica, MA, USA) using the wet transfer method. Nonspecific sites were blocked with $3 \%$ bovine serum albumin (BSA) in Tris-buffered saline/Tween-20 buffer (TBST) at $37^{\circ} \mathrm{C}$ for $4 \mathrm{~h}$. Membranes were then rinsed three times with TBST and incubated overnight $(12-16 \mathrm{~h})$ at $4{ }^{\circ} \mathrm{C}$ with the indicated primary antibodies, followed by incubation with a goat anti-rabbit horseradish peroxidase-conjugated IgG secondary antibody at $26^{\circ} \mathrm{C}$. Table 2 provides the antibodies used and the dilution ratio. 
Table 2

The antibodies and their dilutions used for western blotting.

\begin{tabular}{|c|c|c|}
\hline Antibody & Supplier & Dilution \\
\hline NF-kB & Proteintech 10745-1-AP & $1: 1000$ \\
\hline P- NF-kB & Santa Cruz sc-136548 & $1: 1000$ \\
\hline iNOS & Novusbio NBP1-33780 & $1: 1000$ \\
\hline $\mathrm{IKKa} / \beta$ & Immunoway YT2301 & $1: 1000$ \\
\hline$P-I K K a / \beta$ & Affbiotech AF3013 & $1: 1000$ \\
\hline JNK & Santa Cruz sc-7345 & $1: 500$ \\
\hline P-JNK & ImmunoWay YP0157 & $1: 500$ \\
\hline P38 & Immunoway YT3513 & $1: 800$ \\
\hline P-P38 & Santa Cruz sc-166182 & $1: 800$ \\
\hline ERK & Santa Cruz sc-514302 & $1: 1000$ \\
\hline $\mathrm{p}$-ERK & Santa Cruz sc-81492 & $1: 1000$ \\
\hline c-jun & Bioss bs-0670R & $1: 1500$ \\
\hline P-c-jun & Affbiotech AF3095 & $1: 1000$ \\
\hline c-fos & Abcam ab190289 & $1: 1000$ \\
\hline P-c-fos & Affbiotech AF0132 & $1: 1000$ \\
\hline claudin-1 & Novusbio NBP1-77036 & $1: 1000$ \\
\hline Zo-1 & Novusbio NBP1-85047 & $1: 1000$ \\
\hline Occludin & Abcam ab31721 & $1: 1000$ \\
\hline$\beta$-actin & Absin abs132001 & $1: 1000$ \\
\hline $\lg G(H+L)$ & bs-40295G-IRDye8 & $1: 5000$ \\
\hline
\end{tabular}

\section{Flow cytometry analysis}

Flow cytometry analysis was carried out using the Annexin V-FITC apoptosis detection kit (BD Biosciences, Franklin Lakes, NJ, USA) as described previously (Peng, et al.,2019). After treatment, the samples were harvested and subjected to Annexin V-FITC/propidium iodide double staining for $10 \mathrm{~min}$. Finally, the samples were analyzed by flow cytometry (BD Biosciences).

\section{Cell immunofluorescence assay}


Cell immunofluorescence was analyzed to assess the expression and location of TJ proteins (ZO-1, occludin, claudin-1, and p65) and F-actin (a cytoskeletal protein), as previously described [24]. Briefly, IPEC-J2 cells were seeded on coverslips in a 24-well plate (BD Falcon, Corning Inc., Corning, NY, USA) and allowed to become confluent. After treatment with glycinin and inhibitors, the samples were washed three times with PBS, fixed for 30 min in $4 \%$ polyoxymethylene, and then again washed three times with PBS.

For occludin, claudin-1, ZO-1, p65, and F-actin staining, cells seeded on coverslips were incubated in $0.5 \%$ Triton X-100 for 20 min and then in $0.5 \%$ BSA for $1 \mathrm{~h}$. Subsequently, cells were incubated with primary antibodies (against occludin, claudin-1, ZO-1, and p65) overnight at $4{ }^{\circ} \mathrm{C}$, washed with PBS three times, and then incubated with a FITC-conjugated secondary antibody (dilution 1:100; E-AB-1016) for $2 \mathrm{~h}$. The cell nuclei were stained with DAPI (Abcam, Cambridge, UK). Finally, the coverslips were mounted onto glass slides and observed under a laser scanning confocal microscope (Olympus, Tokyo, Japan). F-actin staining was performed using FITC-phalloidin (Abcam).

\section{EMSA}

To confirm the effects of glycinin on the DNA protein binding activity, EMSA binding reactions were performed as described previously [24]. Briefly, the biotin-labeled AP-1, p65, and CREB were obtained from Nanjing KeyGen Biotech Co., Ltd. (Nanjing, China). After incubation, the total cellular protein-DNA complex was separated on $4 \%$ nondenaturing polyacrylamide gels in Tris-borate EDTA buffer (Nanjing KeyGen Biotech Co., Ltd.) and then transferred and fixed on a nylon membrane. Cold biotin-labeled probes at 25 -fold and 100 -fold excess were employed as controls and visualized by chemiluminescent procedures. The sequence of the consensus oligonucleotide is provided in Table 3.

Table 3

The sequence of the consensus oligonucleotide.

\begin{tabular}{|lll|}
\hline Gene & Primer & Sequences \\
\hline NF-kB p65 & Forward & 5'-AGT TGA GGG GAC TTT CCC AGG C-3' \\
\cline { 2 - 4 } & Reverse & 3'-TCA ACT CCC CTG AAA GGG TCC G-5' \\
CREB & Forward & 5'-AGA GAT TGC CTG ACG TCA GAG AGC TAG-3' \\
& Reverse & 3'-TCT CTA ACG GAC TGC AGT CTC TCG ATC-5' \\
AP-1 & Forward & 5'-CGC TTG ATG ACT CAG CCG GAA-3' \\
& Reverse & 3'-GCG AAC TAC TGA GTC GGC CTT-5' \\
\hline
\end{tabular}

\section{Data analysis}

All results were analyzed with general linear models in SPSS version 20 (SPSS Inc., Chicago, IL, USA). Duncan's multiple range tests were used to assess the differences between means. $p<0.05$ indicated statistically significant differences. The flow cytometry results were processed using FlowJo software 
(FlowJo V10, Ashland, OR, USA), whereas western blotting results were processed using Quantity One one-dimensional analysis software (Bio-Rad, Hercules, CA, USA). Histograms were plotted using statistical software GraphPad Prism version 7 (GraphPad Software, San Diego, CA, USA).

\section{Declarations}

\section{Ethics approval and consent to participate}

Not applicable

\section{Consent for publication}

Not applicable

\section{Availability of data and materials}

All data generated or analysed during this study are included in this published article.

\section{Competing interests}

None

\section{Funding}

This study was supported by the National Natural Science Foundation of China [No. 31972750], the Project of Modern Agricultural Industry and Technology System of Anhui Province (AHCYJSTX-05/07)

\section{Authors' contributions}

conceptualization, Chenglu Peng. ; methodology, Zhifeng Sun.; software, Lei Wang.; writing-original draft preparation, Yingshuang Shu.; writing-review and editing, Mengchu He.; visualization, Hongyan Ding.; supervision, Shibin Feng and Jinchun Li.; project administration, Yu Li. and Xichun Wang.; funding acquisition, JinjieWu.

\section{References}

Akiyama T, Niyonsaba F, Nguyen TT, Smithrithee R, Kiatsurayanon C, Ushio H, et al. Effects of host defense peptide cathelicidin LL-37 on tight junction barrier. J Dermatol Sci. 2013;69: e45-6.

Cargnello M, Roux PP. Activation and function of the MAPKs and their substrates, the MAPK-activated protein kinases. Microbiol Mol Biol Rev. 2011;75:50-83.

Chen CC, Lee TT, Hsu CB, Huang CW, Yu B. Associations of allergenic soybean proteins with piglet skin allergic reaction and application of polyclonal antibodies. Anim Prodn Sci. 2011;51:1008-14. 
Chenglu P, Chengming C, Mengchu H, Yingshuang S, Xuebing T, Yuanhong W, et al. Soybean glycinin- and $\beta$-conglycinin-induced intestinal damage in piglets via p38/JNK/NF-KB signaling pathway. J Agric Food Chem. 2018;66:9534-41.

Cui Y, Wang Q, Chang R, Zhou X, Xu C. Intestinal barrier function-non-alcoholic fatty liver disease interactions and possible role of gut microbiota. J Agric Food Chem. 2019;67:2754-62.

Günzel D, Yu AS. Claudins and the modulation of tight junction permeability. Physiol Rev. 2013;93:525569.

Hao Y, Zhan ZF, Guo PF, Xiangshu P, Li D. Soybean $\beta$-conglycinin-induced gut hypersensitivity reaction in a piglet model. Arch Anim Nutr. 2009;63:188-202.

Hossain MI, Huq S, Islam MM, Ahmed T. Acceptability and efficacy of ready-to-use therapeutic food using soy protein isolate in under- 5 children suffering from severe acute malnutrition in Bangladesh: a doubleblind randomized non-inferiority trial. Eur J Nutr. 2019; doi: 10.1007/s00394-019-01975-w.

Jiang WD, Hu K, Zhang JX, Liu Y, Jiang J, Wu P, et al. Soybean glycinin depresses intestinal growth and function in juvenile Jian carp (Cyprinus carpio var Jian): protective effects of glutamine. $\mathrm{Br} \mathrm{J}$ Nutr. 2015;114:1569-83.

Kim EK, Choi EJ. Pathological roles of MAPK signaling pathways in human diseases. Biochim Biophys Acta 2010;1802:396-405.

Koepke JR, Kaushik RS, Gibbons WR, Brown M, Levesque CL. Evaluation of a bioprocessed soybean meal on nursery pig performance and immune status. J Anim Sci. 2017;95:5030-9.

Li L, Jin G, Jiang J, Zheng M, Jin Y, Lin Z, et al. Cornuside inhibits mast cell-mediated allergic response by down-regulating MAPK and NF-KB signaling pathways. Biochem Biophysl Res Commun. 2016;473:40814.

Li Q, Verma IM. NF-kappaB regulation in the immune system. Nat Rev Immunol. 2002;2:725-34.

Liu X, Feng J, Xu ZR, Wang YZ, Liu JX. Oral allergy syndrome and anaphylactic reactions in BALB/c mice caused by soybean glycinin and beta-conglycinin. Clin Exp Allergy 2008;38:350-356.

Ma X, He P, Sun P, Han P. Lipoic acid: an immunomodulator that attenuates glycinin-induced anaphylactic reactions in a rat model. J Agric Food Chem. 2010;58:5086-92.

Mace TA, Ware MB, King SA, Loftus S, Farren MR, McMichael E, et al. Soy isoflavones and their metabolites modulate cytokine-induced natural killer cell function. Sci Rep. 2019;9:5068.

Mariani V, Palermo S, Fiorentini S, Lanubile A, Giuffra E. Gene expression study of two widely used pig intestinal epithelial cell lines: IPEC-J2 and IPI-2I. Vet Immunol Immunopathol. 2009;131:278-84. 
Martin G, Bogdanowicz P, Domagala F, Ficheux H, Pujol JP. Rhein inhibits interleukin-1 beta-induced activation of MEK/ERK pathway and DNA binding of NF-kappa B and AP-1 in chondrocytes cultured in hypoxia: a potential mechanism for its disease-modifying effect in osteoarthritis. Inflammation 2003;27:233-46.

Maruyama N, Prak K, Motoyama S, Choi SK, Yagasaki K, Ishimoto M, et al. Structure-physicochemical function relationships of soybean glycinin at subunit levels assessed by using mutant lines. J Agric Food Chem. 2004;52:8197-201.

Odenwald MA, Choi W, Buckley A, Shashikanth N, Turner JR. ZO-1 interactions with F-actin and occludin direct epithelial polarization and single lumen specification in 3D culture. J Cell Sci. 2016;130:243-59.

Osaki LH, Gama P. MAPKs and signal transduction in the control of gastrointestinal epithelial cell proliferation and differentiation. Int J Mol Sci. 2013;14:10143-61.

Peng C, Cao C, He M, Shu Y, Tang X, Wang Y, et al. Soybean glycinin- and $\beta$-conglycinin-induced intestinal damage in piglets via the p38/JNK/NF-KB signaling pathway. J Agric Food Chem. 2018;66:9534-41.

Peng C, Ding X, Zhu L, He M, Shu Y, Zhang Y, et al. $\beta$-Conglycinin-induced intestinal porcine epithelial cell damage via the nuclear factor $\mathrm{KB} /$ mitogen-activated protein kinase signaling pathway. J Agric Food Chem. 2019;67:9009-21.

Qiao S, Li D, Jiang J, Zhou H, Thacker PA. Effects of moist extruded full-fat soybeans on gut morphology and mucosal cell turnover time of weanling pigs. Asian-Australas J Anim Sci. 2003;16:63-9.

Roy A, Srivastava M, Saqib U, Liu D, Faisal SM, Sugathan S, et al. Potential therapeutic targets for inflammation in toll-like receptor 4 (TLR4)-mediated signaling pathways. Int Immunopharmacol. 2016;40:79-89.

Shaywitz AJ, Greenberg ME. CREB: a stimulus-induced transcription factor activated by a diverse array of extracellular signals. Annu Rev Biochem. 1999;68:821-61.

Suh SJ, Chung TW, Son MJ, Kim SH, Moon TC, Son KH, et al. The naturally occurring biflavonoid, ochnaflavone, inhibits LPS-induced iNOS expression, which is mediated by ERK1/2 via NF-kappaB regulation, in RAW264.7 cells. Arch Biochem Biophys 2006;447:136-46.

Sun P, Li D, Li Z, Dong B, Wang F. Effects of glycinin on IgE-mediated increase of mast cell numbers and histamine release in the small intestine. J Nutr Biochem. 2008;19:627-33.

Tak PP, Firestein GS. NF-kappaB: a key role in inflammatory diseases. J Clin Invest. 2001;107:7-11.

Weidmann E, Samadi N, Klems M, Heiden D, Seppova K, Ret D, et al. Mouse chow composition influences immune responses and food allergy development in a mouse model. Nutrients 2018;10:pii: E1775. 
Zenz R, Eferl R, Scheinecker C, Redlich K, Wagne EF. Activator protein 1 (Fos/Jun) functions in inflammatory bone and skin disease. Arthritis Res Ther. 2008;10:201.

Zhai Z, Ni X, Jin C, Ren W, Li J, Deng J, et al. Cecropin A modulates tight junction-related protein expression and enhances the barrier function of porcine intestinal epithelial cells by suppressing the MEK/ERK pathway. Int J Mol Sci. 2018;19: pii: E1941.

Zhang Y, Chen P, Liang XF, Han J, Wu XF, Yang YH, et al. Metabolic disorder induces fatty liver in Japanese seabass, Lateolabrax japonicas fed a full plant protein diet and regulated by CAMP-JNK/NF-kBcaspase signal pathway. Fish Shellfish Immunol. 2019;90:223-34.

Zhao Y, Liu D, Han R, Zhang X, Zhang S, Qin G. Soybean allergen glycinin induced the destruction of the mechanical barrier function in IPEC-J2. Food Agr Immunol. 2015;26:601-9.

Zhao Y, Qin G, Sun Z, Zhang X, Bao N, Wang T, et al. (2008). Disappearance of immunoreactive glycinin and beta-conglycinin in the digestive tract of piglets. Arch Anim Nutr. 2008;62: 322-30.

Zheng S, Qin G, Chen J, Zhang F. Acidic polypeptides A1a, A3 and A4 of Gly $\mathrm{m} 6$ (glycinin) are allergenic for piglets. Vet Immunol Immunopathol 2018;202:147-52.

Zheng S, Qin G, Tian H, Sun Z. Role of soybean $\beta$-conglycinin subunits as potential dietary allergens in piglets. Vet J. 2014;199:434-8.

\section{Figures}


Acid subunit

Basic subunit
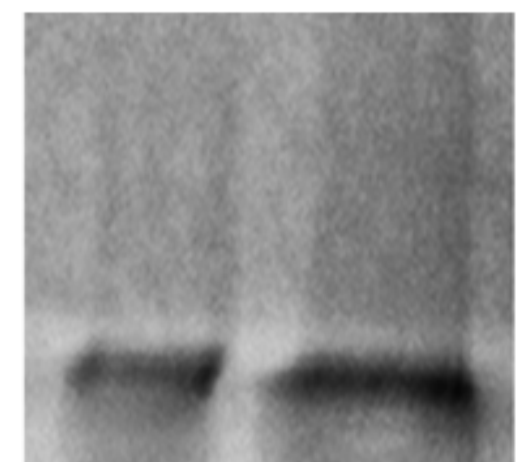

$31-45 \mathrm{kDa}$

$18-20 \mathrm{kDa}$

Figure 1

SDS-PAGE for preparation of $\beta$-conglycinin 
a

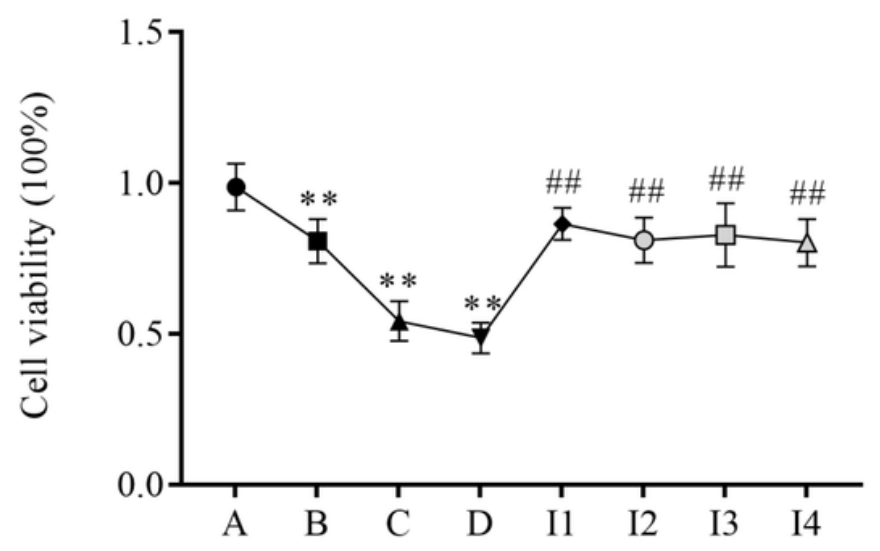

- A: Control group

- B: $1 \mathrm{mg} \cdot \mathrm{mL}^{-1}$ glycinin

- C: $5 \mathrm{mg} \cdot \mathrm{mL}^{-1}$ glycinin

$\rightarrow$ D: $10 \mathrm{mg} \cdot \mathrm{mL}^{-1}$ glycinin

$\rightarrow$ I1: $5 \mathrm{mg} \cdot \mathrm{mL}^{-1}$ glycinin $+1 \mu \mathrm{mol} \cdot \mathrm{L}^{-1}$ PDTC

-O- I2: $5 \mathrm{mg} \cdot \mathrm{mL}^{-1}$ glycinin $+1 \mu \mathrm{mol} \cdot \mathrm{L}^{-1} \mathrm{~L}-\mathrm{NAME}$

- $\square$ I3: $5 \mathrm{mg} \cdot \mathrm{mL}^{-1}$ glycinin $+1 \mu \mathrm{mol} \cdot \mathrm{L}^{-1} \mathrm{SP} 600125$

$\triangle \quad$ I4: $5 \mathrm{mg} \cdot \mathrm{mL}^{-1}$ glycinin $+1 \mu \mathrm{mol} \cdot \mathrm{L}^{-1} \mathrm{SB} 202190$

b

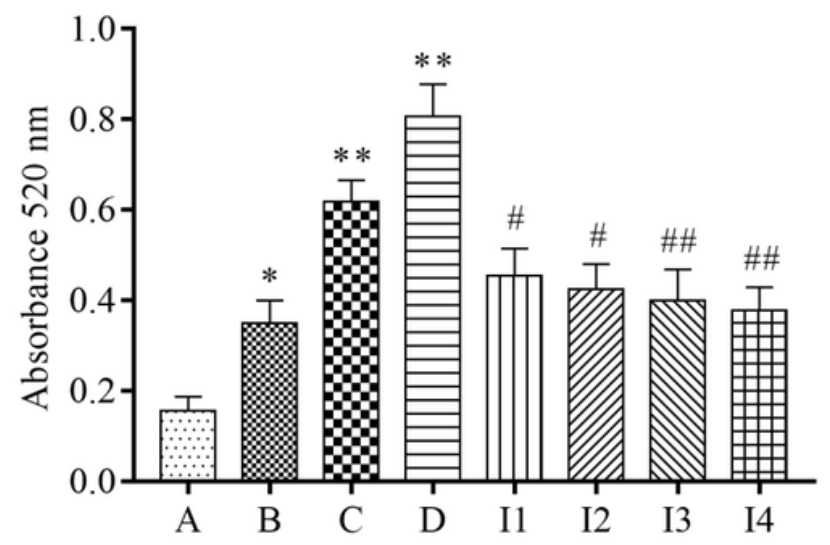

E... A: Control group

B: $1 \mathrm{mg} \cdot \mathrm{mL}^{-1}$ glycinin

$00 \mathrm{C}: 5 \mathrm{mg} \cdot \mathrm{mL}^{-1}$ glycinin

E $\mathrm{D}: 10 \mathrm{mg} \cdot \mathrm{mL}^{-1}$ glycinin

एा I1: $5 \mathrm{mg} \cdot \mathrm{mL}^{-1}$ glycinin $+1 \mu \mathrm{mol} \cdot \mathrm{L}^{-1}$ PDTC

III I2: $5 \mathrm{mg} \cdot \mathrm{mL}^{-1}$ glycinin $+1 \mu \mathrm{mol} \cdot \mathrm{L}^{-1} \mathrm{~L}-\mathrm{NAME}$

M I3: $5 \mathrm{mg} \cdot \mathrm{mL}^{-1}$ glycinin $+1 \mu \mathrm{mol} \cdot \mathrm{L}^{-1} \mathrm{SP} 600125$

世约: $5 \mathrm{mg} \cdot \mathrm{mL}^{-1}$ glycinin $+1 \mu \mathrm{mol} \cdot \mathrm{L}^{-1} \mathrm{SB} 202190$

Figure 2

Cell viability and alkaline phosphatase (ALP) activity. (a) Cell viability after 24-h treatment with glycinin detected by Cell Counting Kit-8 assay. (b) ALP activity of intestinal porcine epithelial cells after 24-h treatment with glycinin. Data are presented as mean \pm standard deviation $(n=3) .{ }^{*} p<0.05$ and ${ }^{* *} p<0.01$ compared with group $A ; \# p<0.05$ and \#\#p $<0.01$ compared with group $C$. 

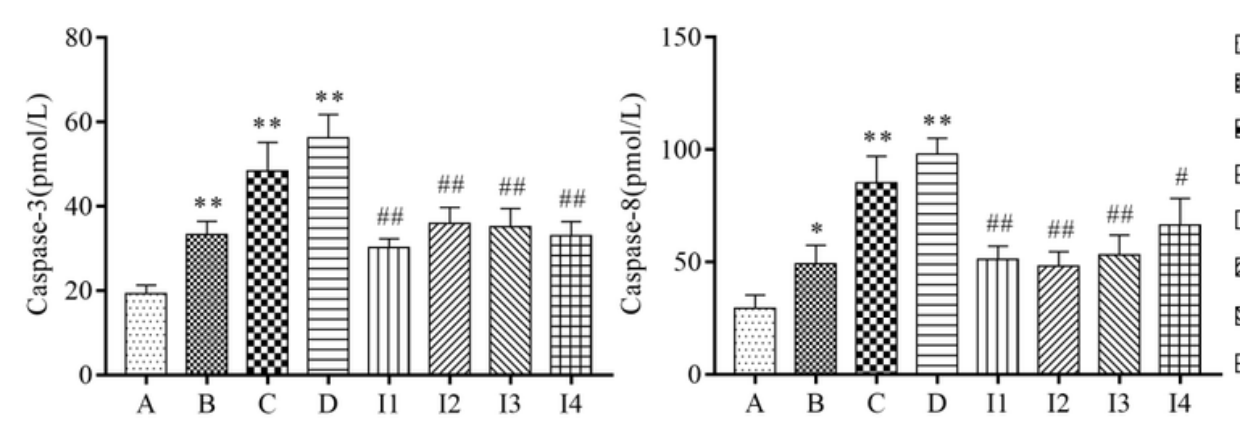

A: Control group
B: $1 \mathrm{mg} \cdot \mathrm{mL}^{-1}$ glycinin

$\$$ C: $5 \mathrm{mg} \cdot \mathrm{mL}^{-1}$ glycinin

$\boxminus \mathrm{D}: 10 \mathrm{mg} \cdot \mathrm{mL}^{-1}$ glycinin

سل I1: $5 \mathrm{mg} \cdot \mathrm{mL}^{-1}$ glycinin $+1 \mu \mathrm{mol} \cdot \mathrm{L}^{-1}$ PDTC

(27) I2: $5 \mathrm{mg} \cdot \mathrm{mL}^{-1}$ glycinin $+1 \mu \mathrm{mol} \cdot \mathrm{L}^{-1} \mathrm{~L}-\mathrm{NAME}$

I3: $5 \mathrm{mg} \cdot \mathrm{mL}^{-1}$ glycinin $+1 \mu \mathrm{mol} \cdot \mathrm{L}^{-1} \mathrm{SP} 600125$

巴 $14: 5 \mathrm{mg} \cdot \mathrm{mL}^{-1}$ glycinin $+1 \mu \mathrm{mol} \cdot \mathrm{L}^{-1} \mathrm{SB} 202190$
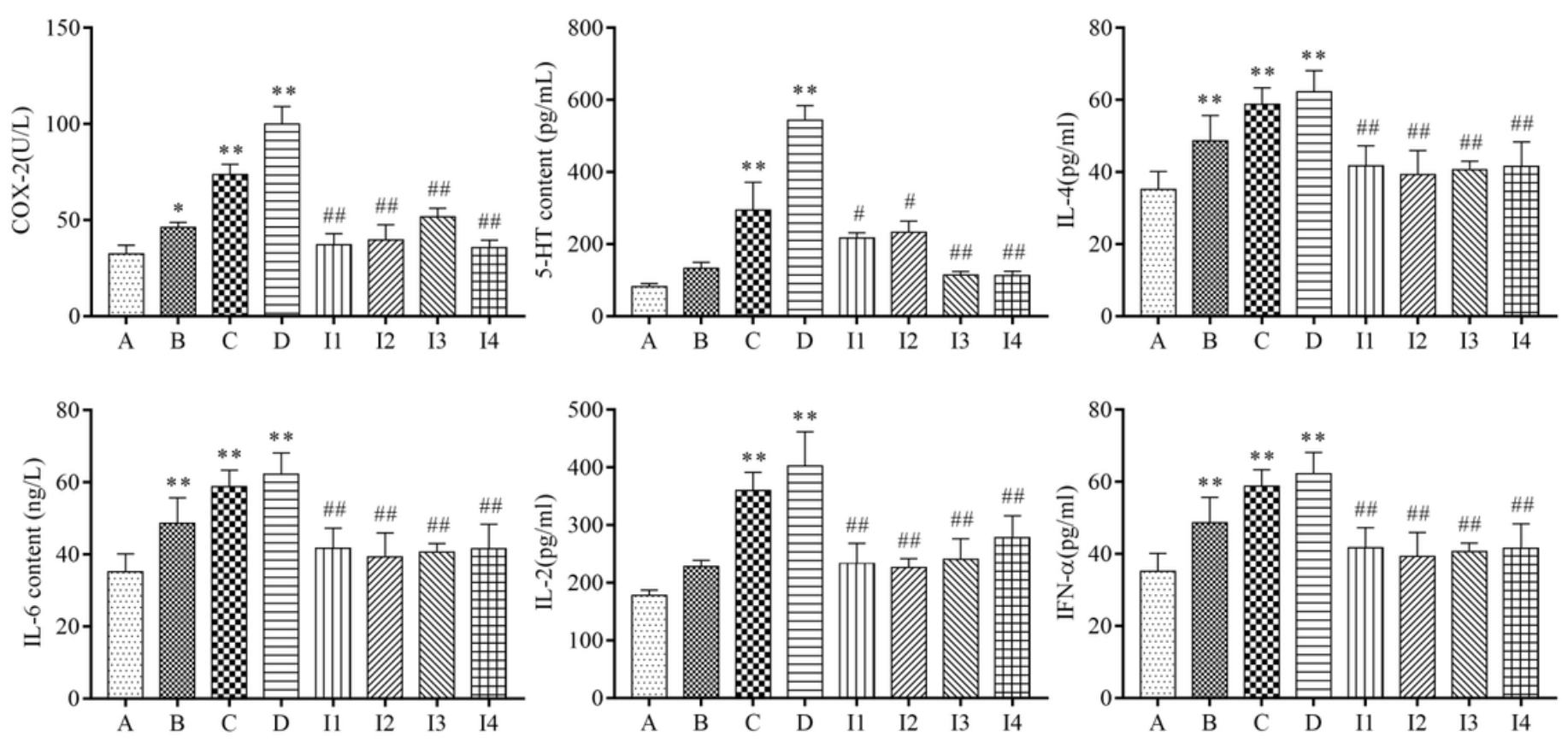

Figure 3

Cytokine expression levels in the intestinal porcine epithelial cells after 24-h treatment with glycinin detected by enzyme-linked immunosorbent assay. Data are presented as mean \pm standard deviation $(\mathrm{n}=$ 3). ${ }^{\star} p<0.05$ and ${ }^{* \star} p<0.01$ compared with group $A$; $\# p<0.05$ and $\# \# p<0.01$ compared with group $C$. 

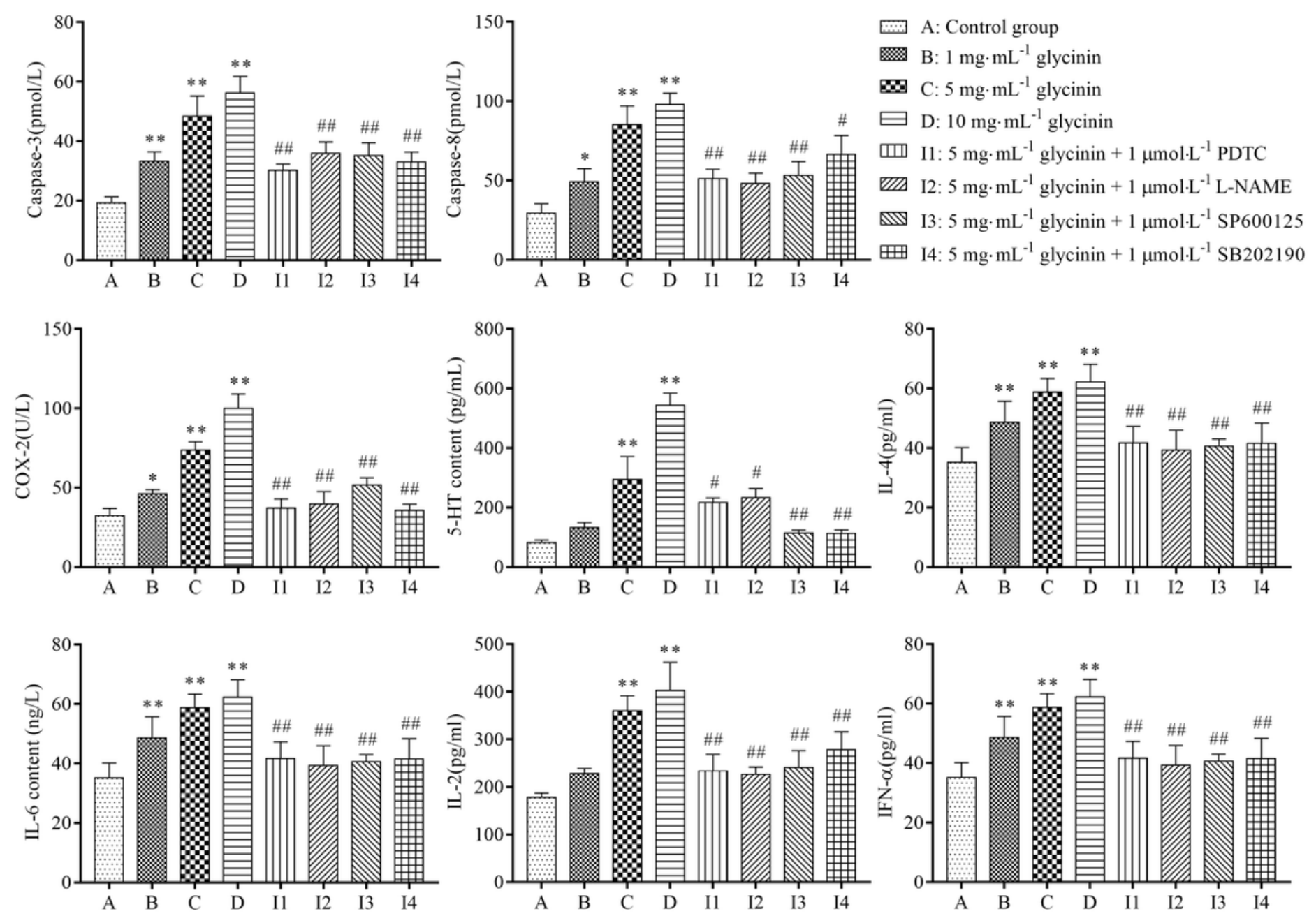

\section{Figure 4}

Electron microscopic images of intestinal porcine epithelial cells after 24-h treatment with glycinin $(5000 x ; 80.0 \mathrm{kV})$. Representative pictures of immunofluorescence staining are provided. 


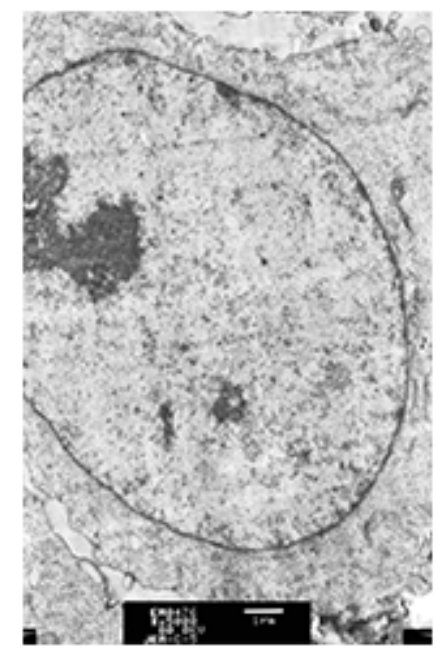

A

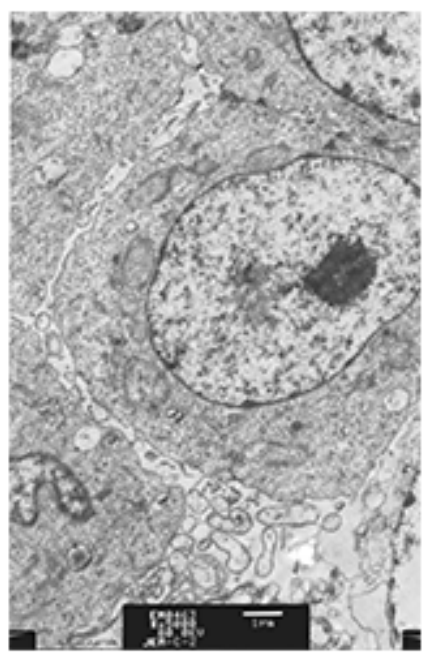

I1

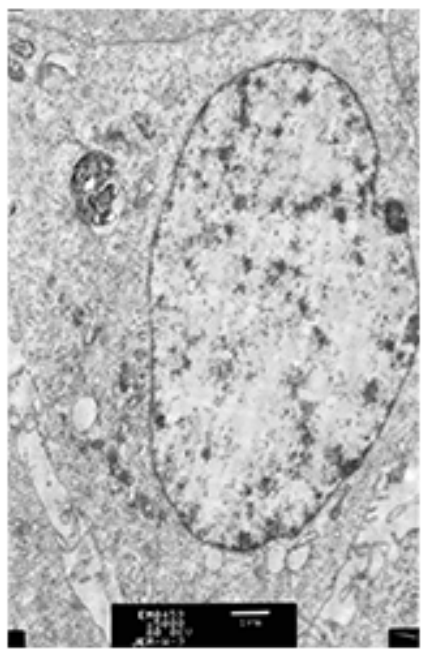

B

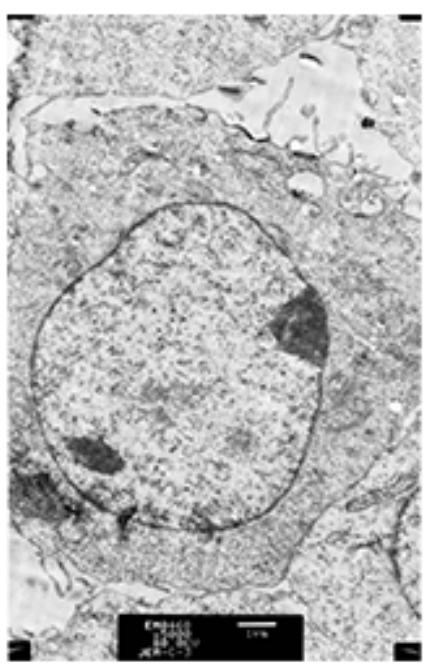

I2

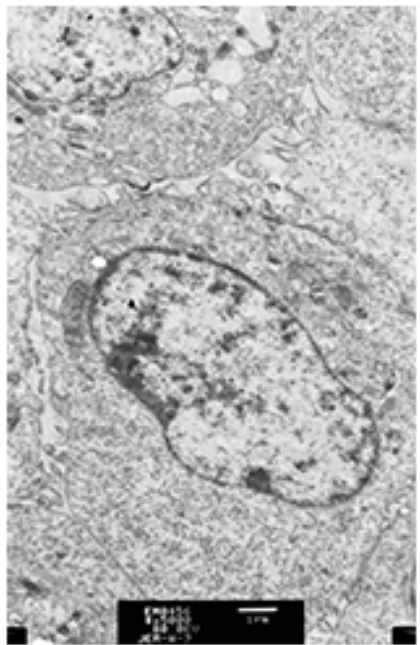

$\mathrm{C}$

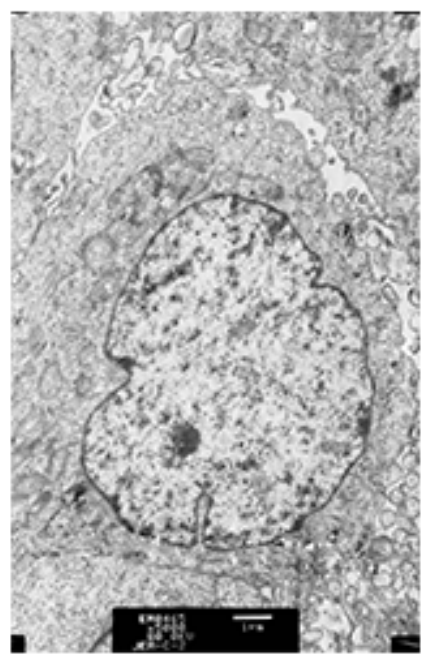

$\mathrm{I} 3$

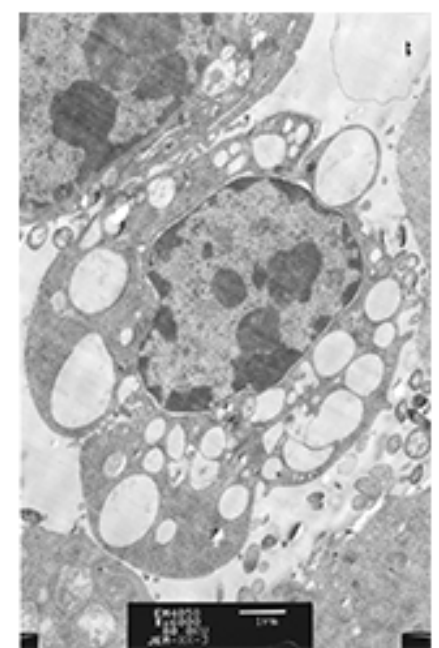

$\mathrm{D}$

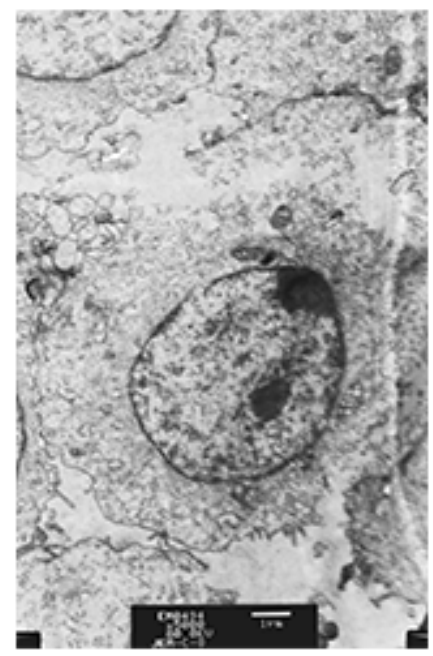

$\mathrm{I} 4$

\section{Figure 5}

Western blotting and qRT-PCR for zonula occludens-1, claudin-1, and occludin in intestinal porcine epithelial cells after 24 - $h$ treatment with glycinin. Data are presented as mean \pm standard deviation $(n=$ 3). ${ }^{*} p<0.05$ and ${ }^{* *} p<0.01$ compared with group $A, \# p<0.05$ and \#\#p $<0.01$ compared with group $C$. 

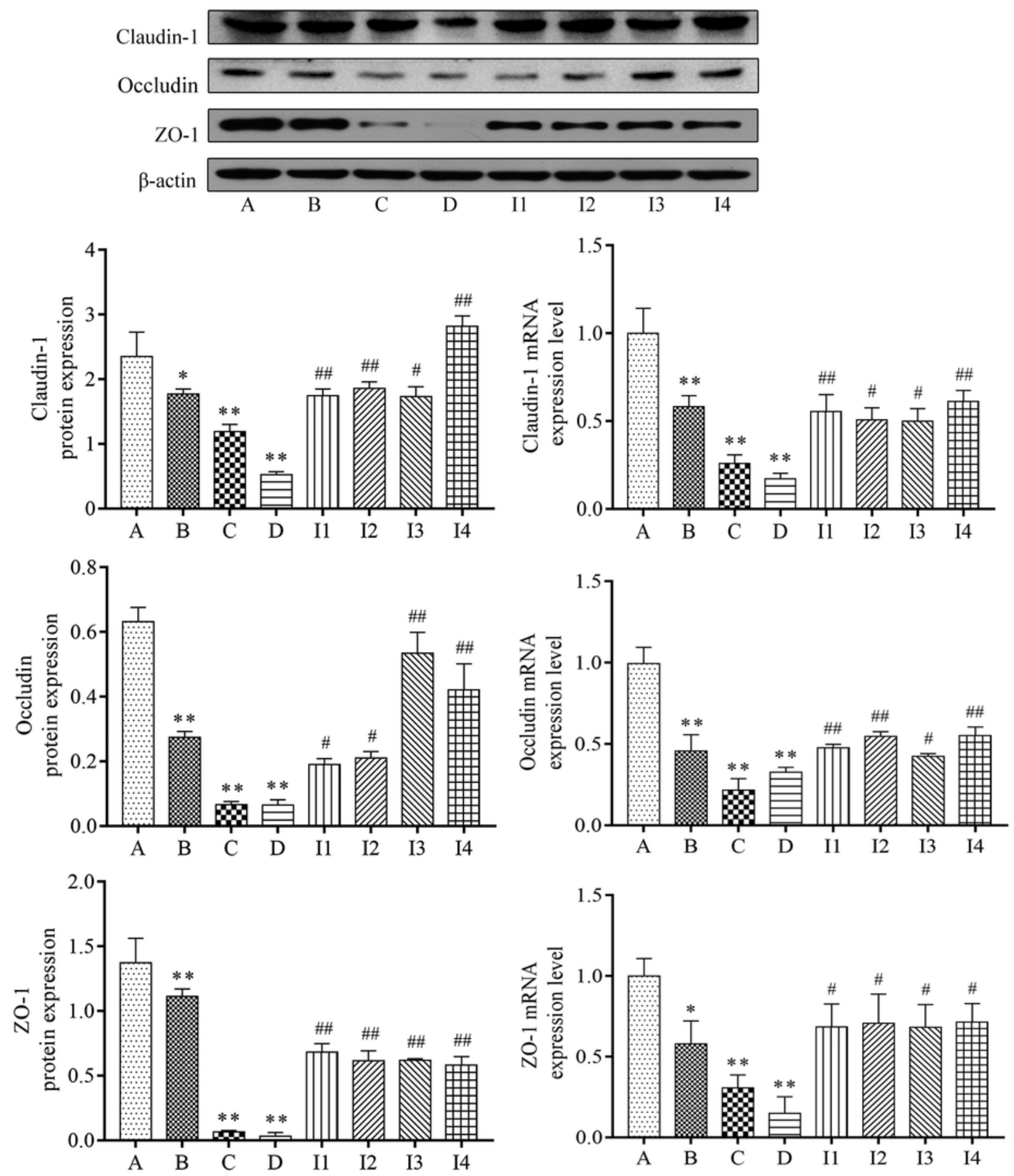

\section{Figure 6}

Claudin-1, occludin, and zonula occludens-1 protein expression in intestinal porcine epithelial cells detected by immunofluorescence after 24-h treatment with glycinin. Representative pictures of immunofluorescence staining (magnification 800x) are provided. 
Claudin-1

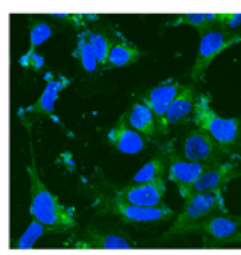

A

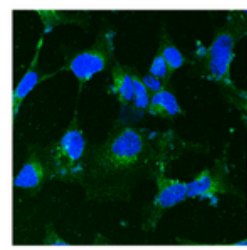

I1

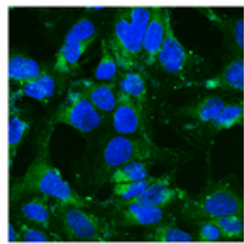

A

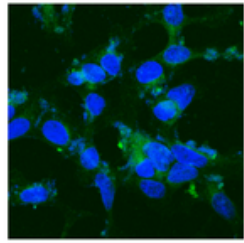

I1

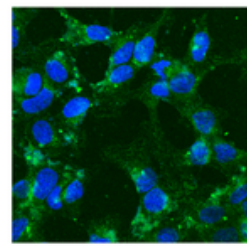

A

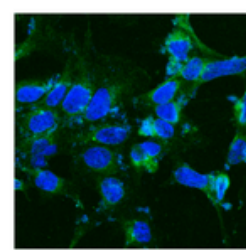

I1

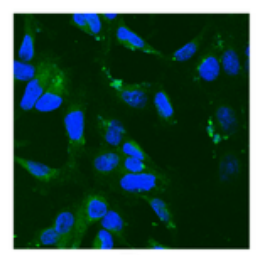

B

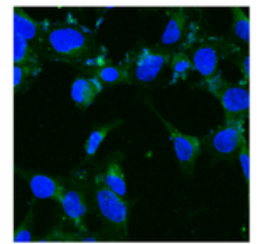

I2

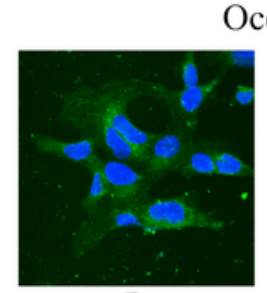

B

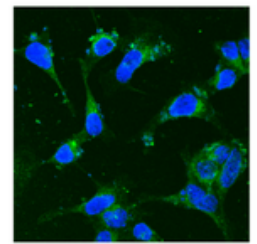

I2

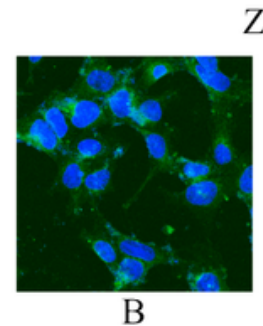

ZO-1

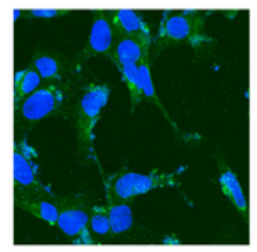

I2
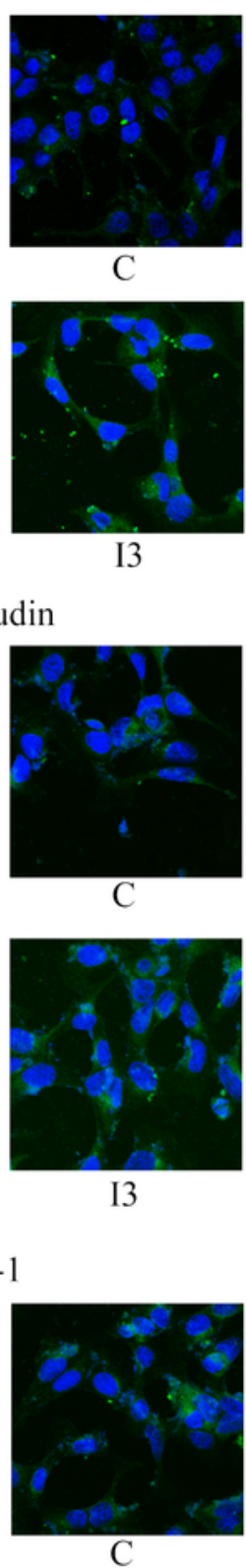

$\mathrm{C}$

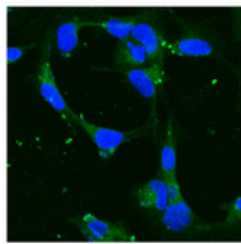

I3

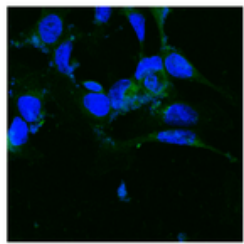

C

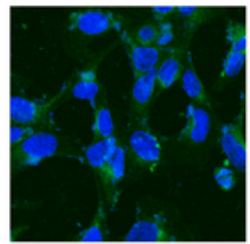

I3

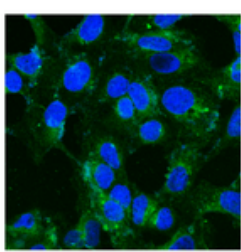

I3
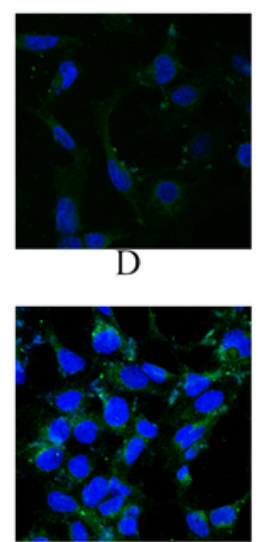

I4

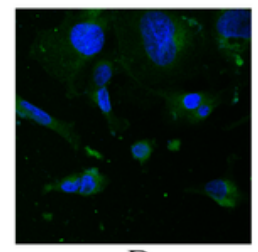

D

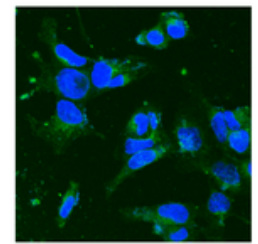

I4
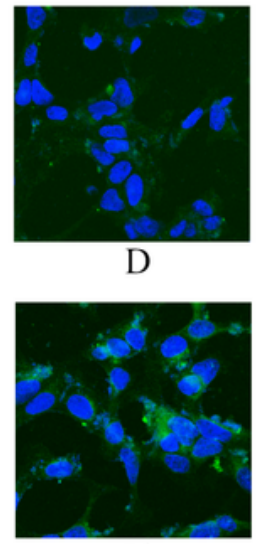

I4

Figure 7

Cytoskeleton proteins in intestinal porcine epithelial cells detected by immunofluorescence after 24-h treatment with glycinin. Representative pictures of immunofluorescence staining (magnification 800x) are provided. 


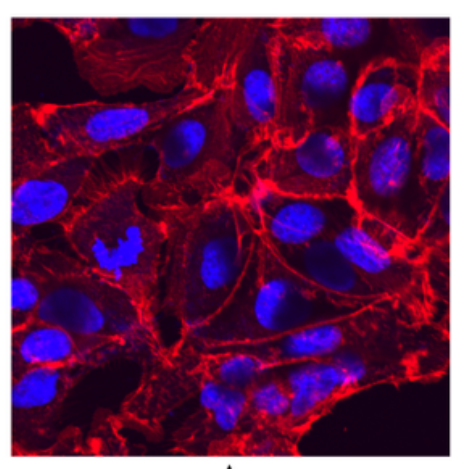

A

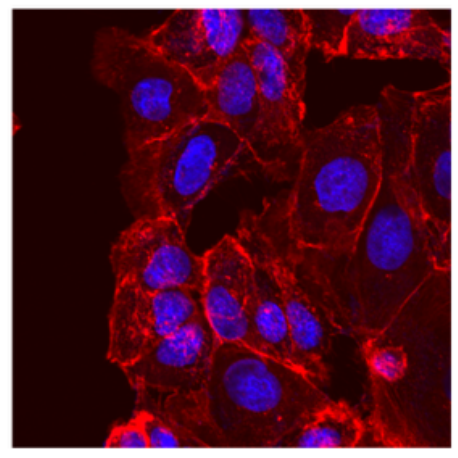

I1

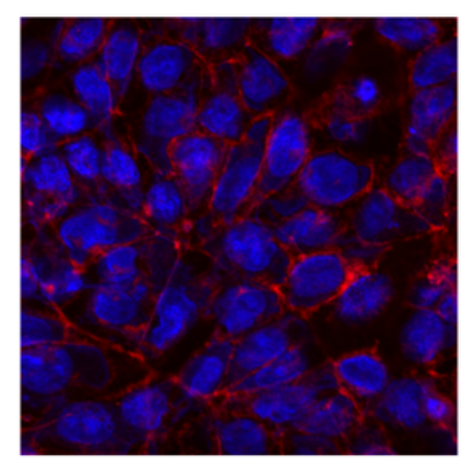

B

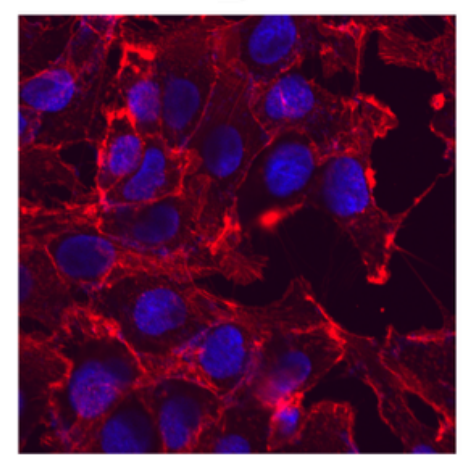

I2

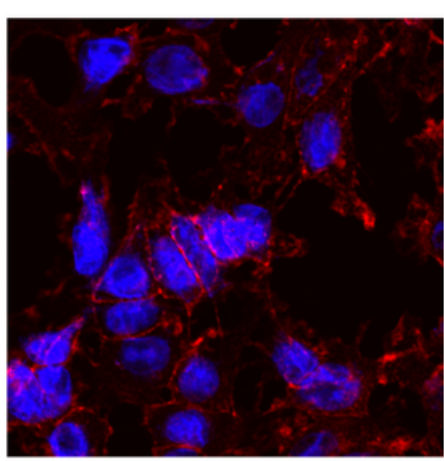

C

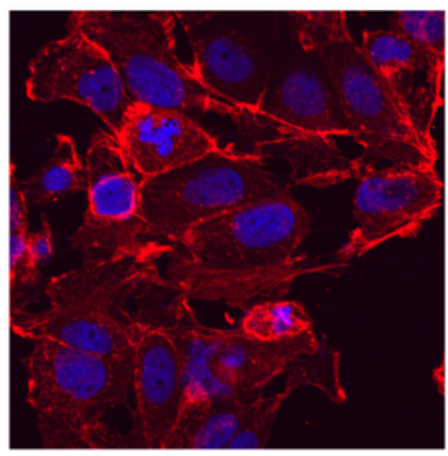

I3

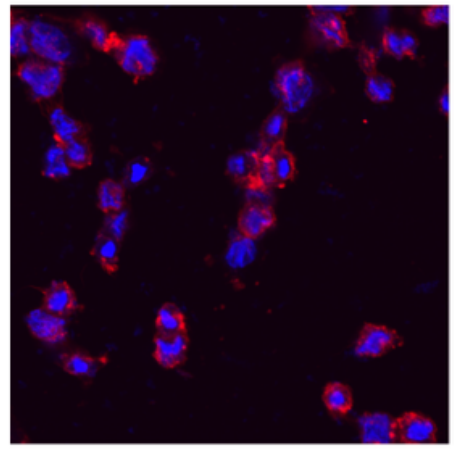

D

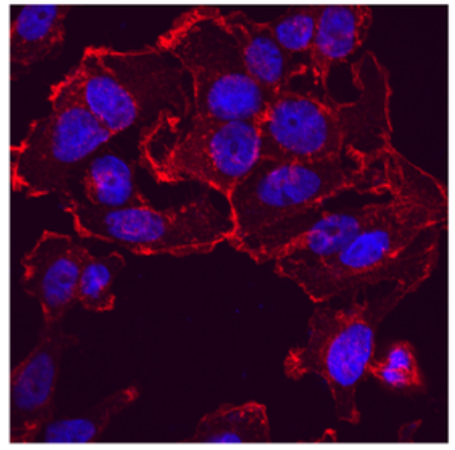

I4

\section{Figure 8}

The mRNA expression of nuclear factor-kappa B (NF-KB), Jun N-terminal kinase (JNK), p38, and their associated genes in intestinal porcine epithelial cells after 24-h treatment with glycinin. Data are presented as mean \pm standard deviation $(n=3)$. ${ }^{\star} p<0.05$ and ${ }^{*} p<0.01$ compared with group $A$; \#p $<$ 0.05 and \#\#p $<0.01$ compared with group C. 

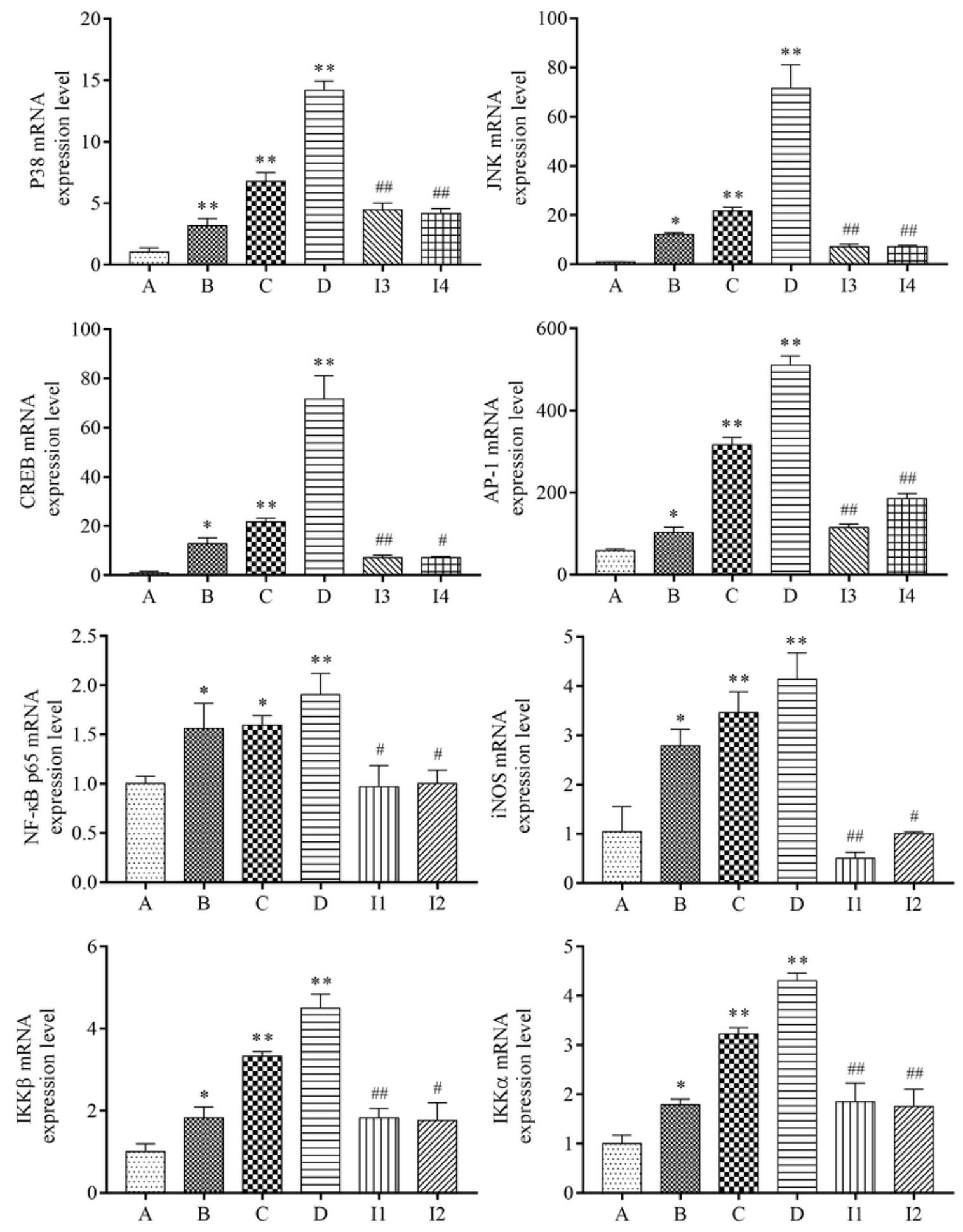

\section{Figure 9}

Western blotting to detect phosphorylation levels of Jun N-terminal kinase (JNK), p38, extracellular signal-regulated kinase (ERK), c-Jun, and c-Fos in intestinal porcine epithelial cells after 24-h treatment with glycinin. Data are presented as mean \pm standard deviation $(n=3)$. ${ }^{*} p<0.05$ and ${ }^{* \star} p<0.01$ compared with group $A ; \# p<0.05$ and \#\#p $<0.01$ compared with group $C$. 


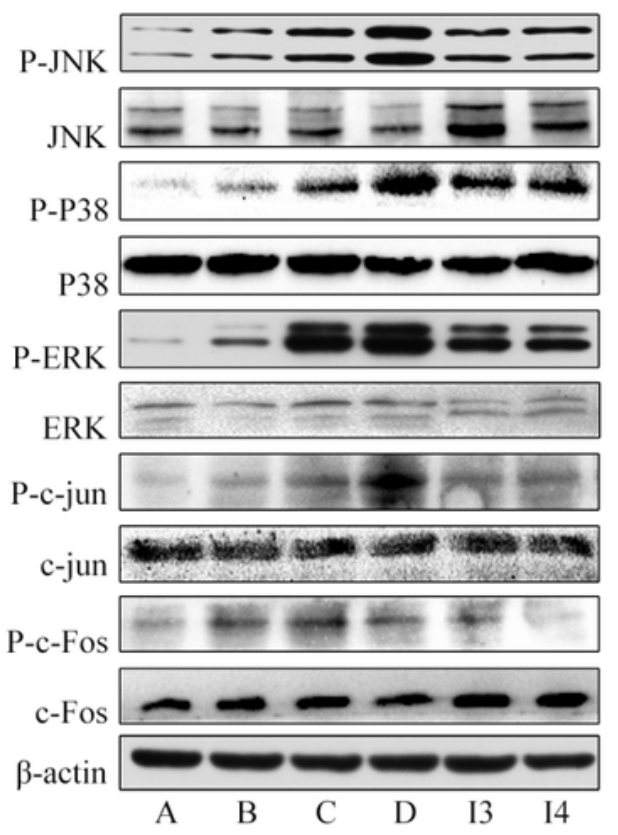

A: Control group
B: $1 \mathrm{mg} \cdot \mathrm{mL}^{-1}$ glycinin
C: $5 \mathrm{mg} \cdot \mathrm{mL}^{-1}$ glycinin
$\square$ D: $10 \mathrm{mg} \cdot \mathrm{mL}^{-1}$ glycinin

I3: $5 \mathrm{mg} \cdot \mathrm{mL}^{-1}$ glycinin $+1 \mu \mathrm{mol} \cdot \mathrm{L}^{-1} \mathrm{SP} 600125$

曲 I4: $5 \mathrm{mg} \cdot \mathrm{mL}^{-1}$ glycinin $+1 \mu \mathrm{mol} \cdot \mathrm{L}^{-1} \mathrm{SB} 202190$
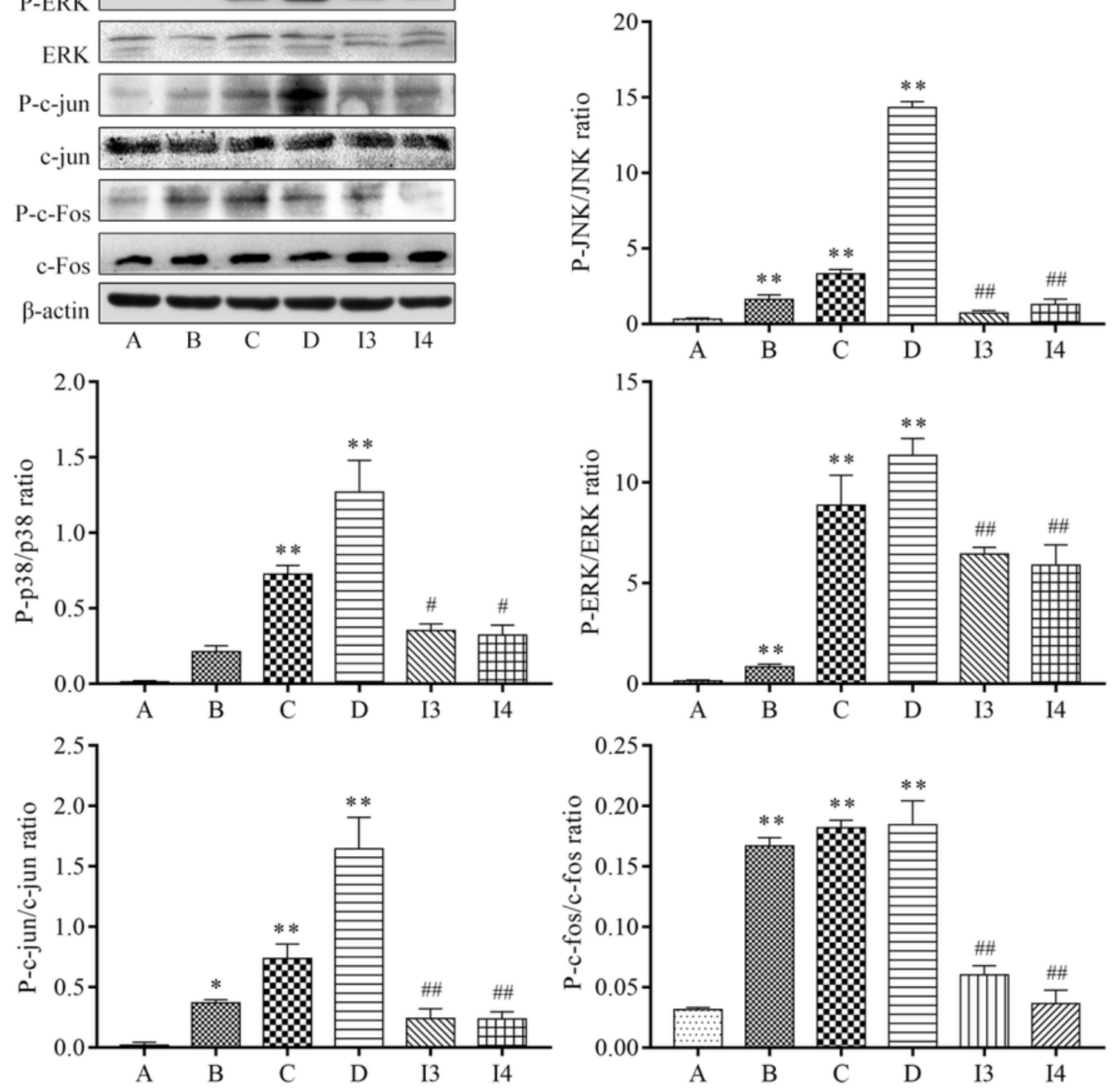

\section{Figure 10}

Phosphorylation levels of nuclear factor-kappa B (NF-kB), inducible nitric oxide synthase (iNOS), and $I \mathrm{KKa} / \beta$ in intestinal porcine epithelial cells detected by western blotting after 24 -h treatment with glycinin. Data are presented as mean \pm standard deviation $(n=3)$. ${ }^{\star} p<0.05$ and ${ }^{* *} p<0.01$ compared with group A, \#p $<0.05$ and \#\#p $<0.01$ compared with group $C$. 


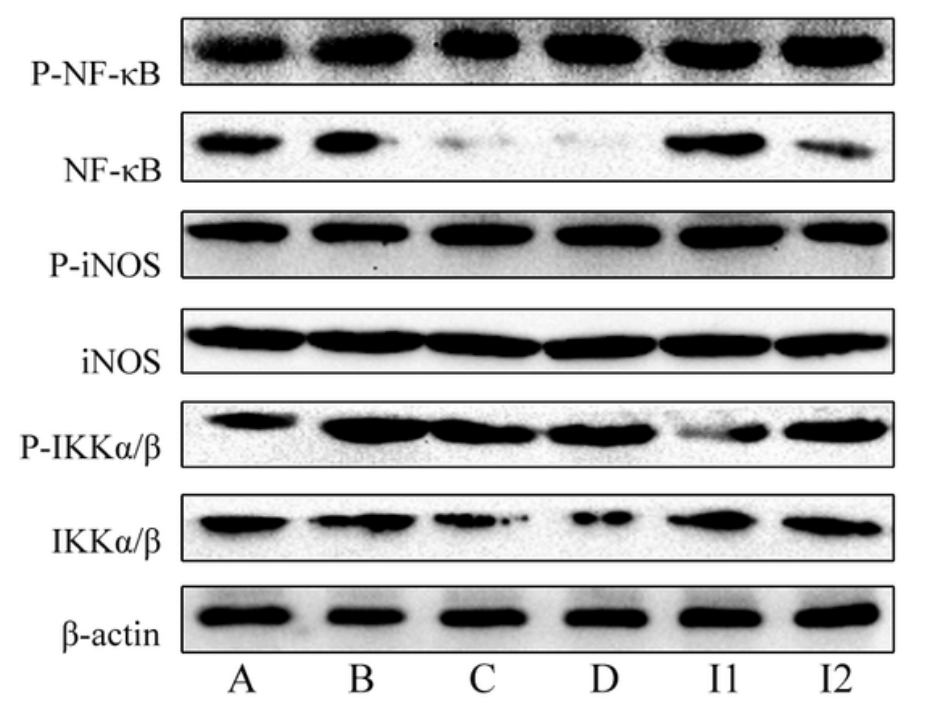

A: Control group

B: $1 \mathrm{mg} \cdot \mathrm{mL}^{-1}$ glycinin

$\mathbf{C}$ C: $5 \mathrm{mg} \cdot \mathrm{mL}^{-1}$ glycinin

曰 D: $10 \mathrm{mg} \cdot \mathrm{mL}^{-1}$ glycinin

س 11 : $5 \mathrm{mg} \cdot \mathrm{mL}^{-1}$ glycinin $+1 \mu \mathrm{mol} \cdot \mathrm{L}^{-1}$ PDTC

IIת I2: $5 \mathrm{mg} \cdot \mathrm{mL}^{-1}$ glycinin $+1 \mu \mathrm{mol} \cdot \mathrm{L}^{-1}$ L-NAME
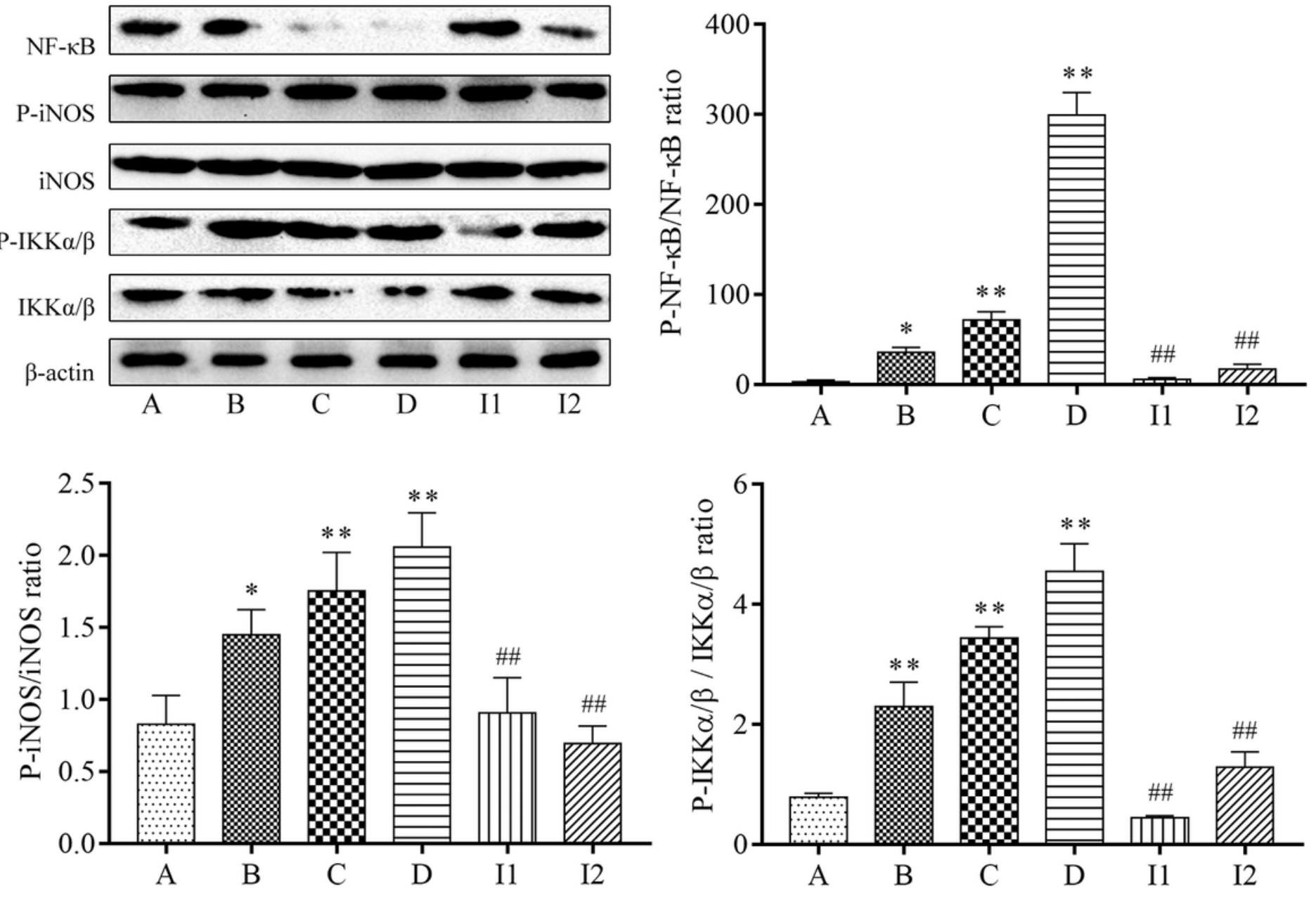

\section{Figure 11}

Nuclear factor-kappa B (NF-KB) protein expression in intestinal porcine epithelial cells detected by immunofluorescence after 24-h incubation with glycinin. Representative pictures of immunofluorescence staining (magnification 800x) are shown. 


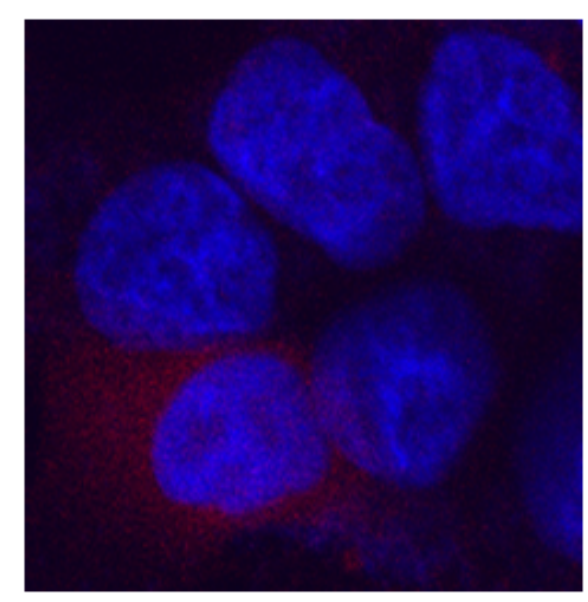

A
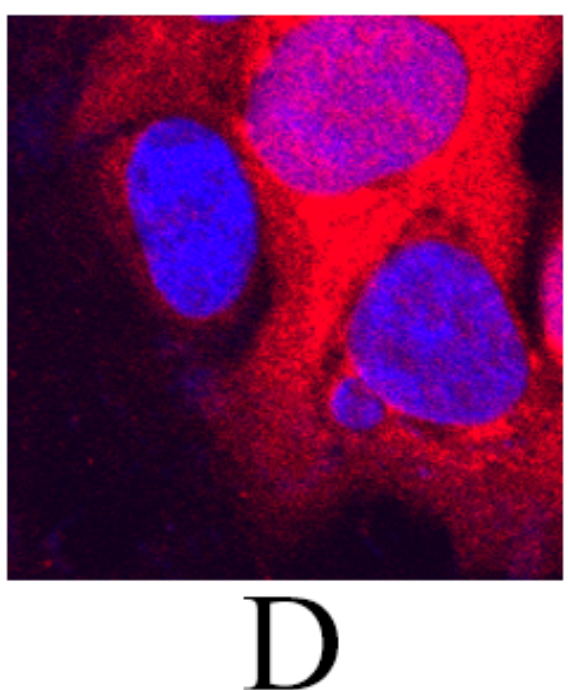

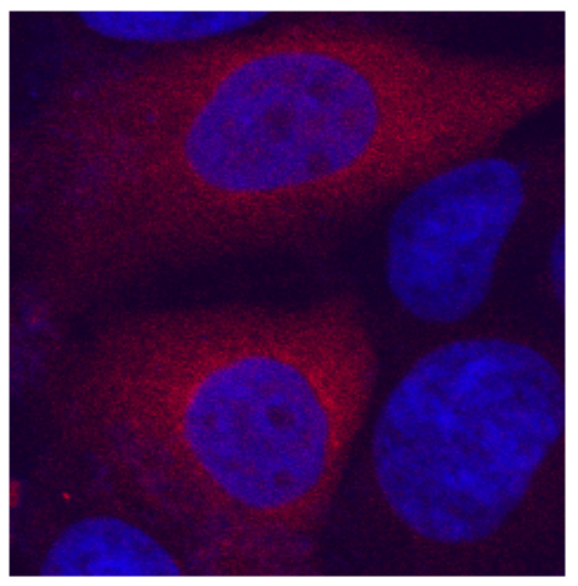

$\mathrm{B}$

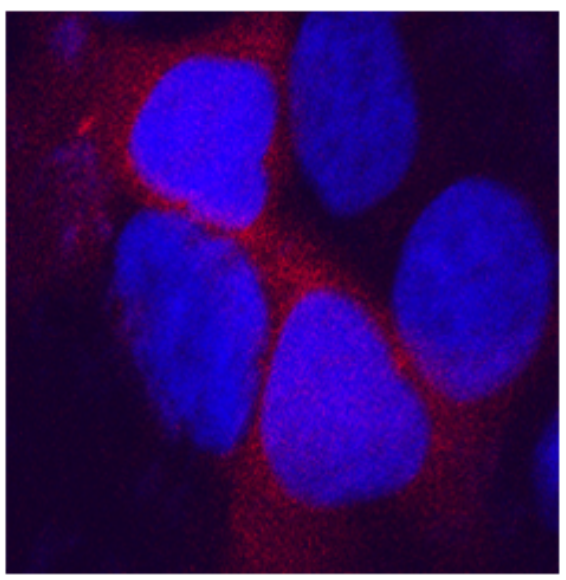

I1

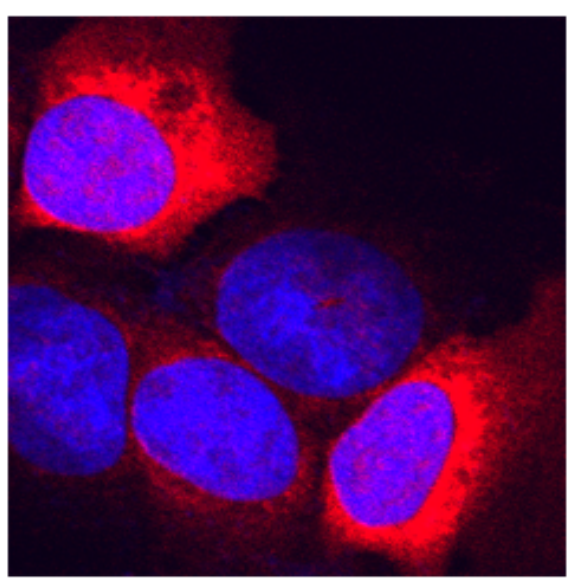

$\mathrm{C}$

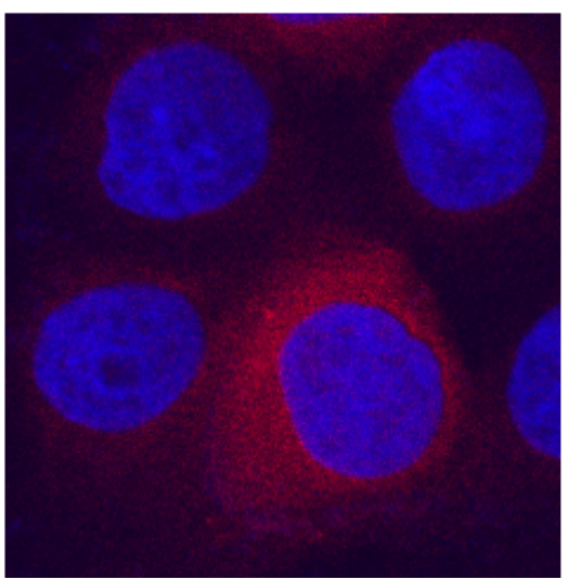

$\mathrm{I} 2$

Figure 12

Proportion of apoptotic intestinal porcine epithelial cells detected by flow cytometry after 24-h treatment with glycinin. Data are presented as mean \pm standard deviation $(n=3) .{ }^{*} p<0.05$ and ${ }^{* \star} p<0.01$ compared with group A, \#p $<0.05$ and \#\#p $<0.01$ compared with group $C$. 

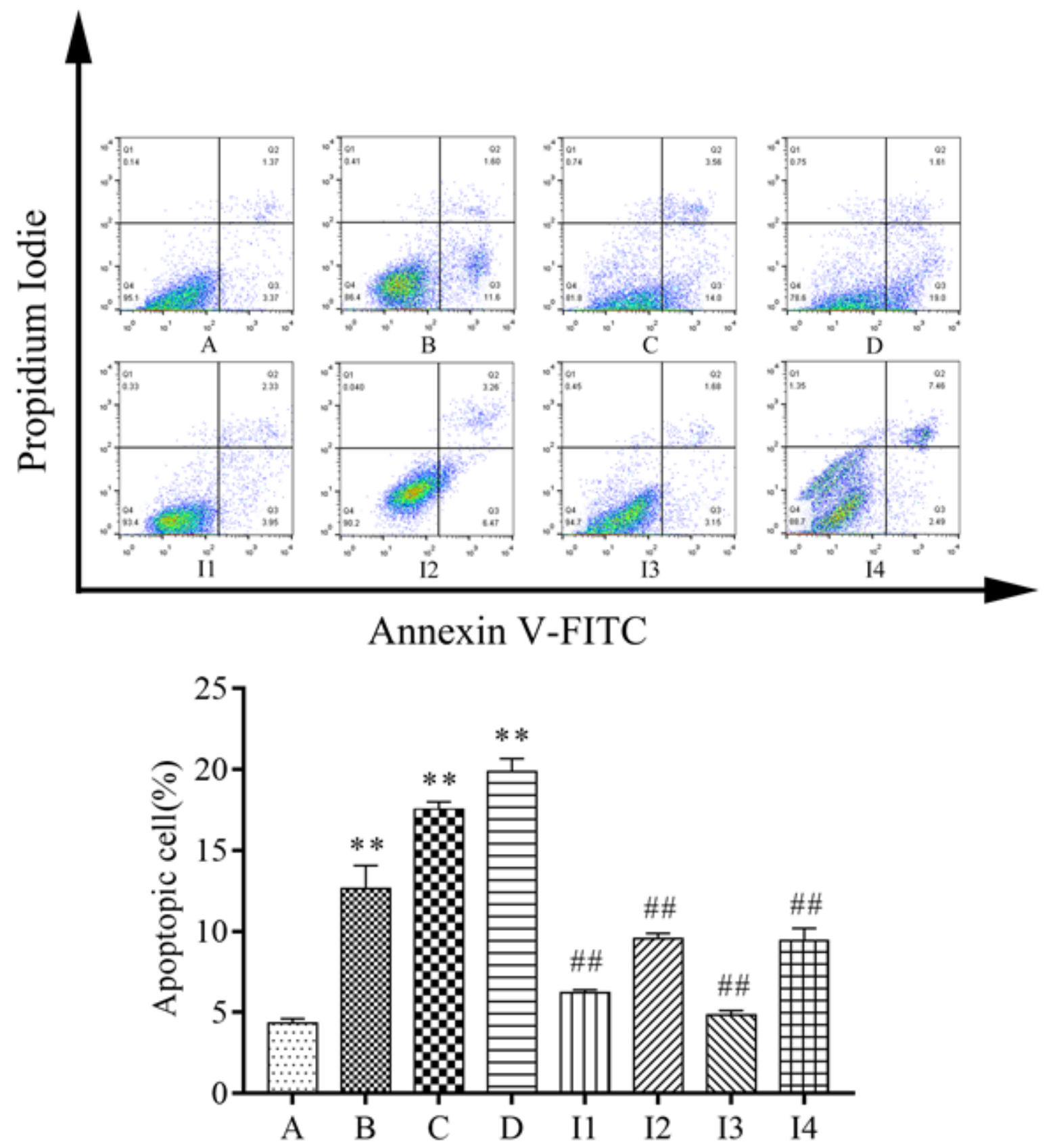

Figure 13

DNA-binding activity of nuclear factor-kappa B (NF-kB), p65, cAMP response element-binding protein (CREB), and activator protein-1 (AP-1) in intestinal porcine epithelial cells detected by electrophoretic mobility shift assay after $24-\mathrm{h}$ treatment with glycinin. Data are presented as mean \pm standard deviation $(n=3) .{ }^{*} p<0.05$ and ${ }^{* *} p<0.01$ compared with group $A ; \# p<0.05$ and \#\#p $<0.01$ compared with group C. 

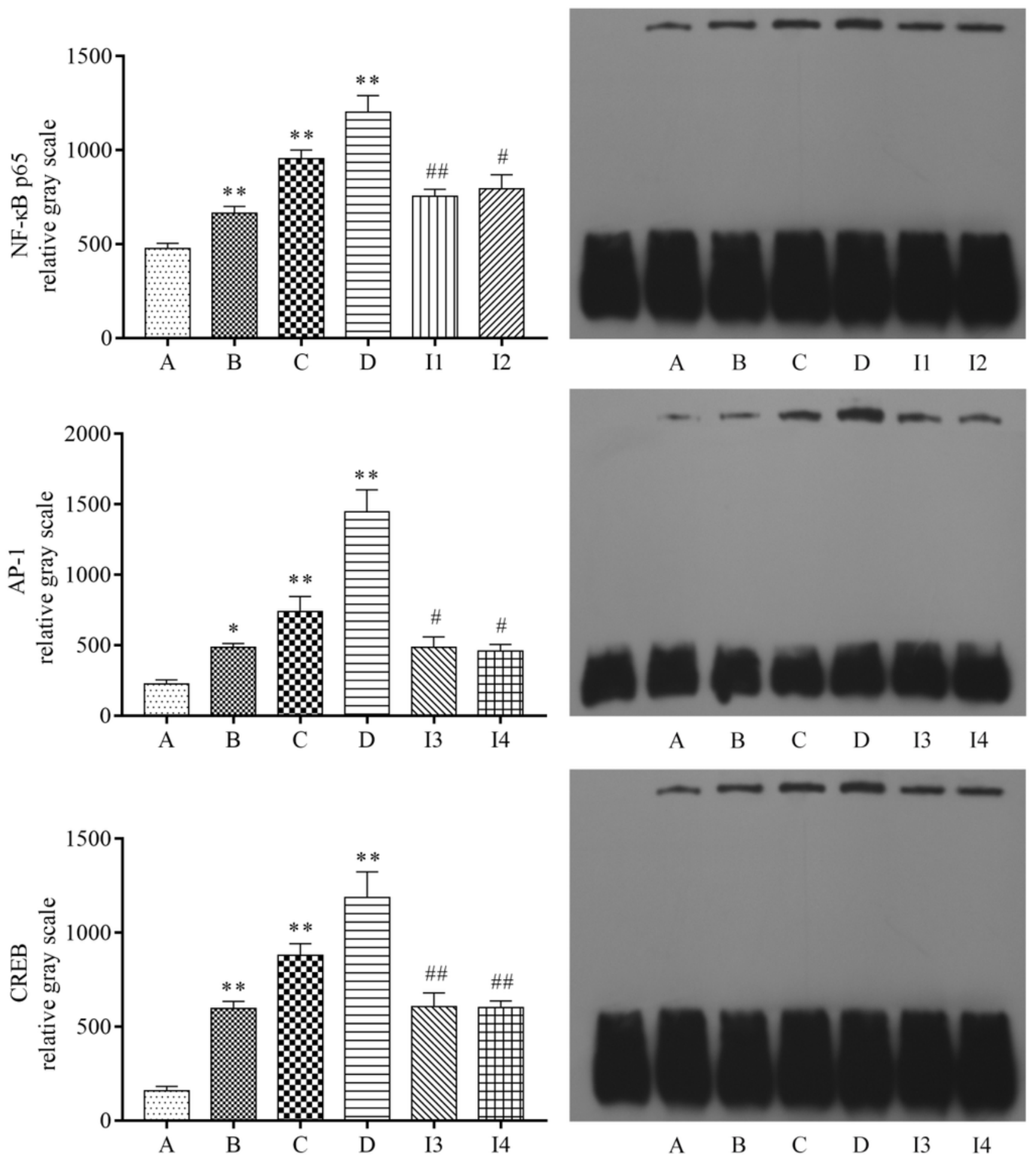

Figure 14 